\title{
Light-induced redox cycling of iron in circumneutral lakes
}

\author{
Lukas Emmenegger, ${ }^{1}$ René Schönenberger, Laura Sigg, and Barbara Sulzberger ${ }^{2}$ \\ Swiss Federal Institute for Environmental Science and Technology (EAWAG), CH-8600 Dübendorf, Switzerland
}

\begin{abstract}
The light-induced redox cycling of $\mathrm{Fe}^{\mathrm{II}} / \mathrm{Fe}^{\mathrm{III}}$ was studied both in laboratory experiments and in the field in two circumneutral Swiss lakes: Greifensee, a eutrophic, natural water body, and Melchsee, an oligotrophic, artificial mountain lake. To determine $\mathrm{Fe}^{\mathrm{II}}$ at the nanomolar level, an automated flow-injection analysis system was used. Irradiation by simulated sunlight leads to $\mathrm{pH}$ dependent $\left(\mathrm{pH}\right.$ 6.9-9.1) steady-state $\mathrm{Fe}^{\mathrm{II}}$ concentrations which are similar in samples from both lakes. However, the kinetics of $\mathrm{Fe}^{\mathrm{III}}$ reduction and of apparent $\mathrm{Fe}^{\mathrm{II}}$ oxidation are considerably faster in Melchsee. On the basis of experimental results and on modeling that uses literature values of known chemical transformation processes, we suggest that superoxide may be a key parameter for light-induced iron redox cycling in these lakes. Field measurements of $\left[\mathrm{Fe}^{\mathrm{II}}\right]$ in Greifensee and Melchsee show a pronounced day/ night cycle, with $\mathrm{Fe}^{\mathrm{II}}$ concentrations of $\sim 0.1-0.2 \mathrm{nM}$ at night and up to $0.9 \mathrm{nM}$ near the surface during the day ( $\mathrm{pH}$ 8.0-8.5). Depth profiles of [Fe $\left.{ }^{\mathrm{II}}\right]$ have two maxima: one at the surface and the second one at a depth of 5-10 $\mathrm{m}$. Empirical rates and measured physical parameters were included in a model to simulate [Fe $\left.\mathrm{Fe}^{\mathrm{II}}\right]$ as a function of time and depth. The model results indicate that $\mathrm{Fe}^{\mathrm{II}}$ at the surface of both lakes is produced by light-induced processes, whereas the deeper $\mathrm{Fe}^{\mathrm{II}}$ maxima at depths with maximal chlorophyll $a$ concentrations are probably due to a combination of biologically and photochemically induced processes.
\end{abstract}

In aquatic ecosystems, iron plays a central role in numerous chemical and biological processes. In cells, iron exists in more than one oxidation state. This allows iron to act as an important cofactor in the electron transport chain and in redox enzymes, including cytochromes and iron-sulfur proteins, e.g., ferredoxin. Along with molybdenum, iron is an essential micronutrient, necessary for nitrate reduction and thus for the assimilation of nitrogen by algae (Sunda et al. 1991). Iron has been shown to be a widespread limiting factor for the growth of phytoplankton in "high nitrate, low chlorophyll" (HNLC) oceanic regions (Coale et al. 1996; Behrenfeld and Kolber 1999; Cavender Bares et al. 1999). In coastal waters and lakes, because of larger particulate inputs, total iron concentrations are generally higher than those in the oceans, making direct limitation of phytoplankton growth seem unlikely. Yet, in these aquatic systems, the abundance of bioavailable iron may favor one class of algae over the other, and thus have a pronounced impact on the ecosystem (Bruland et al. 1991). Furthermore, the possibility that iron concentrations may be sufficiently low to limit algal growth has been suggested for the very oligotrophic Lake

\footnotetext{
${ }^{1}$ Present address: Swiss Federal Laboratories for Materials Testing and Research, CH-8600 Dübendorf, Switzerland.

${ }^{2}$ Corresponding author (Barbara.Sulzberger@eawag.ch)

Acknowledgements

We thank D. W. King for many stimulating discussions and for his continuous support for $\mathrm{Fe}^{\mathrm{II}}$ analysis. Gerrit-Hein Goudsmit has calculated the diffusion coefficients and introduced us to Aquasim. The following persons are acknowledged for their help with photochemical experiments or field sampling: Monique Gehriger, Renata Hari, Lisette Hari, Stefan Hug, Edith Kaiser, David Kistler, Lukas Kurmann, Elio Larcan, Hansueli Laubscher, Suzanne Mettler, Niksa Odzak, Ursula Schoenenberger, Dani Steiner, and Diane Weirich. We also acknowledge the helpful suggestions offered by the reviewers.
}

This work has been supported by the Swiss National Science Foundation.
Tahoe (Chang et al. 1992), and iron has been shown to restrict phytoplankton growth in high phosphorous saline lakes (Evans and Prepas 1997) and in hard-water calcareous lakes (Schelske 1962; Schelske et al. 1962; Wetzel 1965).

Most photosynthetic organisms can take up iron only in dissolved and weakly complexed form (Anderson and Morel 1982; Harrison and Morel 1986; Hudson and Morel 1990; Sunda and Huntsman 1995; Sunda in press). In oxygen-containing water bodies of circumneutral $\mathrm{pH}$, the thermodynamically stable form of iron is $\mathrm{Fe}^{\mathrm{III}}$, whose solubility is extremely low (Millero 1997). In sunlit surface waters, $\mathrm{Fe}^{\mathrm{III}}$ can, however, be reduced to $\mathrm{Fe}^{\mathrm{II}}$ through various mechanisms involving dissolved $\mathrm{Fe}^{\mathrm{III}}$, poly $\mathrm{Fe}^{\mathrm{III}}$ hydroxo complexes or colloidal $\mathrm{Fe}^{\mathrm{III}}$ (hydr)oxides. Reduction of dissolved $\mathrm{Fe}^{\mathrm{III}}$, which is in competition with precipitation, can occur by (1) photolysis of organic and inorganic $\mathrm{Fe}^{\mathrm{III}}$ complexes (Waite and Morel 1984; King et al. 1993; Voelker and Sulzberger 1996), (2) reduction of dissolved, inorganic $\mathrm{Fe}^{\mathrm{III}}$ by superoxide (Miller et al. 1995; Voelker and Sedlak 1995), (3) reduction of $\mathrm{Fe}^{\mathrm{III}}$ at cell surfaces, a process that is linked to biological photosynthesis (Jones et al. 1987; Price and Morel 1990), and (4) thermal, abiotic reduction of $\mathrm{Fe}^{\mathrm{III}}$ by organic reductants, e.g., humic acid (Deng and Stumm 1994; Voelker and Sulzberger 1996). Ferrous iron has a much higher solubility and generally forms weaker complexes with organic ligands than $\mathrm{Fe}^{\text {III }}$. It is, therefore, directly-or, after oxidation to bioavailable forms of $\mathrm{Fe}^{\mathrm{III}}$-accessible to eucaryotic phytoplankton through their membrane-bound ligands (Hudson and Morel, 1990). In oxygen-containing water bodies at circumneutral $\mathrm{pH}, \mathrm{Fe}^{\mathrm{II}}$ is rapidly oxidized, yielding $\mathrm{Fe}^{\mathrm{III}}$, where both $\mathrm{O}_{2}$ and $\mathrm{H}_{2} \mathrm{O}_{2}$ may be rate-determining oxidants. In a recent study, Emmenegger et al. (1998) found the half-life of $\mathrm{Fe}^{\mathrm{II}}$ in the epilimnion of Greifensee in summer $(\mathrm{pH} 8.0$ $8.5 ; \mathrm{O}_{2} \approx 300 \mu \mathrm{M}$, and $\mathrm{H}_{2} \mathrm{O}_{2}=50-200 \mathrm{nM}$ ) to range between 7 and $60 \mathrm{~s}$.

The formation of $\mathrm{Fe}^{\mathrm{II}}$ in surface seawater has been examined by measuring $\mathrm{Fe}^{\mathrm{II}}$ in situ as a function of depth or 
time of day (Hong and Kester 1986; Elrod et al. 1991; Gledhill and van den Berg 1995; Waite et al. 1995) or by measuring $\mathrm{Fe}^{\mathrm{II}}$ during irradiation of seawater samples (O’Sullivan and Hanson 1991; Johnson et al. 1994). Depth profiles of $\mathrm{Fe}^{\mathrm{II}}$ in the upper $100 \mathrm{~m}$ of the equatorial Pacific were both temporally and spatially variable but generally exhibited maxima near the surface and often at depths with maximal chlorophyll $a$ concentrations. Under irradiation of water samples from the Pacific Ocean with a solar simulator, $\mathrm{Fe}^{\mathrm{II}}$ concentrations increased to $\sim 4 \mathrm{nM}$ (at $\mathrm{pH} 6.50$ ) and 0.3 nM (at pH 8.15) after 3 h (O'Sullivan and Hanson 1991). Waite et al. (1995) demonstrated diel variation of the $\mathrm{Fe}^{\mathrm{II}}$ concentration that paralleled the intensity of sunlight in northern Australian shelf waters. In freshwater, research has been limited to acidic conditions (Collienne 1983; Sulzberger et al. 1990), the oxic/anoxic boundary in lakes (Hamilton-Taylor and Davison 1995), and one study in Lake Kinneret (Sivan et al. 1998). The observation of diel Fe $\mathrm{Fe}^{\mathrm{II}}$ cycling strongly indicates that sunlight plays a central role in the formation of $\mathrm{Fe}^{\mathrm{II}}$ in the euphotic zone of surface waters. None of the above-mentioned freshwater studies have included time series of depth profiles that would reflect photon flux as a function of both daytime and depth.

This study investigates the redox cycling of iron in two circumneutral Swiss lakes both in the field and in laboratory experiments. The field data of $\left[\mathrm{Fe}^{\mathrm{II}}\right]$ as a function of time and depth are modeled by use of empirical $\mathrm{Fe}^{\mathrm{III}}$ reduction and $\mathrm{Fe}^{\mathrm{II}}$ oxidation rates obtained from laboratory experiments. A second kinetic model based on known reactions and reaction rates is employed to elucidate the predominant pathways for light-induced iron redox cycling.

\section{Materials and methods}

Field sites and field setup-Greifensee is a highly eutrophic lake in central Switzerland with a surface area of 8.5 $\mathrm{km}^{2}$ and a volume of $150 \times 10^{6} \mathrm{~m}^{3}$. Its average depth is $17.7 \mathrm{~m}$, with a maximum of $33 \mathrm{~m}$. In summer, dissolved organic carbon (DOC) is typically $330 \mu \mathrm{M}$ and alkalinity $\sim 3.9 \mathrm{mM}$. Melchsee is an oligotrophic artificial mountain lake with a surface area of $0.5 \mathrm{~km}^{2}$, situated at an altitude of $1891 \mathrm{~m}$. Its maximum depth is $16 \mathrm{~m}$, DOC is $<80 \mu \mathrm{M}$ and alkalinity typically $1.5 \mathrm{mM}$. Its catchment area $\left(5.9 \mathrm{~km}^{2}\right)$ is very rich in iron minerals. The $\mathrm{pH}$ in the epilimnion is $>8$ in both lakes. Water samples were collected from the water column at their deepest point.

Samples were sucked by a peristaltic pump through a 25 $\mathrm{m}, 6 \mathrm{~mm}$ ID Teflon tube with a Teflon weight, unless stated otherwise. The tubing could be lowered down to $\sim 15 \mathrm{~m}$ within the water column and was held in place at a distance of $5 \mathrm{~m}$ from the boat by a system of aluminum pipes. For sampling and filtration, the water was pumped directly into a Plexiglas box equipped with a ventilator and clean air filter. Within the clean air box, a $0.73-\mathrm{mm}$ Teflon bypass was connected to supply sample for $\mathrm{Fe}^{\mathrm{II}}$ analysis. Pump speeds were adjusted to guarantee analysis of the samples within $<60 \mathrm{~s}$. All samples and reagents were stored in a coolbox.

Materials_All solutions were prepared by use of $18 \mathrm{M} \Omega$ NANOpure water. Chemicals of pro analysis quality were used as received unless stated otherwise. Ammonium ferrous sulfate hexahydrate, 5-amino-2,3-dihydrophthalazin-1,4-dion (Luminol), p-hydroxyphenylacetic acid purum, and quinine sulfate dihydrate were obtained from Fluka. $\mathrm{HNO}_{3} 65 \%$ suprapure, $\mathrm{HCl} 30 \%$ suprapure, $\mathrm{NH}_{3} 25 \%$ suprapure and hydrogen peroxide $30 \%$ were purchased from Merck. Peroxidase, grade II, from horseradish (HRP) and catalase from beef liver were from Boehringer-Mannheim. One unit HRP will oxidize $1 \mu \mathrm{mol}$ guaiacol (tetramer) per minute, and one unit catalase will decompose $1 \mu \mathrm{mol}$ of $\mathrm{H}_{2} \mathrm{O}_{2}$ in $1 \mathrm{~min}$ at $25^{\circ} \mathrm{C}$ and $\mathrm{pH}$ 7.0. Sterile 25-mm Syringe Filters were either from Gelman Sciences (0.45 $\mu \mathrm{m}$ Acrodisc) or Whatman (0.02 $\mu \mathrm{m}$ Anotop). All other filters were cellulose nitrate, purchased from Sartorius. Samples and reagents used for metal analysis were stored in polypropylene bottles that had been soaked at least $24 \mathrm{~h}$ in $0.01 \mathrm{M} \mathrm{HCl}$ and rinsed three times with NANOpure water. Filtered samples were stored in Teflon bottles that had been cleaned by the same procedure. Freshly distilled $\mathrm{HNO}_{3}$ suprapure was used to acidify samples for metal analysis.

Iron analysis-Samples were filtered through 25-mm syringe filters immediately after sampling. The syringes were placed in parallel on a manifold which connected up to six samples to one vacuum source. Ultrafiltered $(0.02 \mu \mathrm{m}) \mathrm{sam}-$ ples were obtained by fixing 0.45 - and $0.02-\mu \mathrm{m}$ filters in series to the syringe. Preliminary tests showed reproducible results for up to $30 \mathrm{ml}$ of lake water before clogging changed the filter conditions significantly. Total iron was determined after acidification of the raw samples to $\mathrm{pH} 2$. Iron was analyzed by use of a Perkin-Elmer 5100 GF-AAS with a THGA graphite tube atomizer. Samples containing $<20 \mathrm{nM}$ Fe were preconcentrated three times by injecting $20 \mu \mathrm{l}$ of sample and drying for $50 \mathrm{~s}$ at $130^{\circ} \mathrm{C}$. The detection limit was $3 \mathrm{nM}$ for the preconcentrated samples.

$\mathrm{Fe}^{\mathrm{II}}$ concentrations were followed by use of an automated flow-injection analysis system employing a luminol-based chemiluminescence detection of $\mathrm{Fe}^{\mathrm{II}}$. An alkaline luminol solution is mixed with the Fe ${ }^{\mathrm{II}}$ sample in front of a photomultiplier. At $\mathrm{pH}>9, \mathrm{Fe}^{\mathrm{II}}$ is rapidly oxidized by oxygen on a millisecond timescale, catalyzing the oxidation of luminol and producing blue light (King et al. 1995; Emmenegger et al. 1998). Calibration was done by standard addition after adjusting the sample $\mathrm{pH}$ to $\sim 7.5$ with artificial air containing $0.5 \%-2 \% \mathrm{CO}_{2}$. At this $\mathrm{pH}$, oxidation of $\mathrm{Fe}^{\mathrm{II}}$ cannot be neglected but is easily accounted for by extrapolating the signal for the time zero after the standard addition, under the assumption of first-order oxidation kinetics. The stability and intensity of the analytical signal is to some extent variable and requires regular recalibration. It depends, among others, on the sample, the quality of the pump tubing, the flow cell, the purity of the reagents used for the luminol-buffer, and light conditions. The detection limit was nevertheless always below $0.5 \mathrm{nM}$, mostly better than $0.2 \mathrm{nM}$. A detailed description of the experimental setup in the laboratory and for online field measurements is given elsewhere (Emmenegger 1999).

Perturbation of the sample could be caused by light penetrating through the Teflon tubing or by oxidation of $\mathrm{Fe}^{\mathrm{II}}$ between sampling and analysis. However, samples were nev- 
er exposed to direct sunlight because of the Teflon tubing, the water column, the aluminum tubing, and the shade on board. In addition, oxidation of $\mathrm{Fe}^{\mathrm{II}}$ is not as fast as would be expected from the oxidation rate in lake water that had not been previously irradiated. This is due to light-induced reduction of $\mathrm{Fe}^{\text {III }}$ (see below). We have estimated the total error during sampling to be $<25 \%$. This has been confirmed by laboratory experiments in which the length of Teflon tubing between the irradiated sample and the analytical system was repeatedly changed to simulate field sampling.

Other methods - $\mathrm{pH}$ measurements were made in the laboratory by use of an Orion Ross electrode and an Orion meter calibrated with NBS buffers. Buffers and samples were both kept at $25^{\circ} \mathrm{C}$ unless stated otherwise. In the field, a WTW pH electrode, NBS (National Bureau of Standards) buffers and a WTW Multiline P4 Universal Meter or WTW pH 323 were used. Alkalinity was determined by automated Gran-titration with use of a Mettler DL 70 ES titrator. DOC was measured by high-temperature catalytic combustion with a Shimadzu 500. $\mathrm{H}_{2} \mathrm{O}_{2}$ was determined by the fluorometric method (Miller and Kester 1988) modified by Emmenegger (1999).

$\mathrm{UV} /$ visual spectra were obtained with a Varian Cary $1 \mathrm{E}$ UV-Visible Spectrophotometer. Photosynthetically active radiation (PAR) was measured with a LI-COR SPQA quantum sensor connected to a LI-1000 data logger. To obtain light profiles in the water column, a second identical sensor was used to monitor incident radiation at the lake surface. UVA/ UVB irradiance was measured by use of LI-COR SD-104A/ B-cos sensors and a LI-1000 data logger. The response curves of the UV sensors cover both a wavelength window of $\sim 80 \mathrm{~nm}$ with a maximum at $312 \mathrm{~nm}$ for the UVA and at $368 \mathrm{~nm}$ for the UVB sensor.

High-resolution temperature and conductivity profiles in lakes were obtained with a sensor (Meeres Electronic, D) connected to a PC for online data acquisition. $\mathrm{O}_{2}$ was measured using a Clark electrode on a $30 \mathrm{~m}$ cable with a batterypowered stirrer connected to a WTW Multiline P4 Universal Meter. Samples for Chlorophyll $a(\mathrm{Chl} a)$ determination were filtered within $1 \mathrm{~h}$ on Whatman glass-fiber filters that were immediately stored in $90 \%$ ethanol and extracted within 24 h. The pigments were analyzed by high-performance liquid chromatography with photometric detection at $430 \mathrm{~nm}$.

Fluorescence of lake-water samples was measured with a Perkin Elmer LS-3 fluorescence spectrophotometer with the excitation set to $430 \mathrm{~nm}$, and the emission measured at 663 $\mathrm{nm}$. Samples were stored in the dark at $<10^{\circ} \mathrm{C}$ for maximum of $1 \mathrm{~h}$ before analysis. Wind direction and speed were continuously measured on top of the boat (Greifensee) or at the lake shore (Melchsee) with a Windsensor (R. M. Young) connected to a HOBO StowAway (Onset) data logger.

To oxidize organic matter, samples were irradiated with light from a mercury lamp for $6 \mathrm{~h}$ in a photooxidation unit (La Jolla Scientific) and stored for $48 \mathrm{~h}$ at $4^{\circ} \mathrm{C}$. Photoproduced $\mathrm{H}_{2} \mathrm{O}_{2}$ was eliminated for the determination of oxidation rates by treatment with $1000 \mathrm{U} \mathrm{L}^{-1}$ catalase for $1-2 \mathrm{~h}$ at $4^{\circ} \mathrm{C}$. About $85 \%$ of DOC was oxidized by this treatment.
Table 1. Iron fractionation in Greifensee (29 June 1998, 2 m depth) and Melchsee (17 October 1998). Melchsee samples were collected at $0.1,5$, and $15 \mathrm{~m}$ depth. The colloidal and particulate fractions have been calculated (see text).

\begin{tabular}{lrcccr}
\hline \hline Fe $[\mathrm{nM}]$ & Unfiltered & $<0.45 \mu \mathrm{m}$ & $<0.02 \mu \mathrm{m}$ Colloidal & $\begin{array}{c}\text { Parti- } \\
\text { culate }\end{array}$ \\
\hline Greifensee & $81 \pm 2$ & $67 \pm 7$ & $49 \pm 9$ & 18 & 14 \\
Melchsee & $364 \pm 9$ & $92 \pm 5$ & $9 \pm 2$ & 83 & 272 \\
\hline
\end{tabular}

Photochemical experiments-Samples in Greifensee were taken on 12 October 1998 with a Go-Flow bottle, 2 m below the surface. DOC was $380 \mu \mathrm{M}$, alkalinity was $3.9 \mathrm{mM}$, and $\mathrm{pH}$ was 8.3. Melchsee samples were collected on 17 October with a Teflon tube connected to a peristaltic pump, $2 \mathrm{~m}$ below the surface at its deepest point. DOC was $80 \mu \mathrm{M}$, alkalinity was $1.4 \mathrm{mM}$, and $\mathrm{pH}$ was 8.3 . For two additional experiments, fresh Melchsee samples were collected on 12 December 1998, $1 \mathrm{~m}$ below the frozen surface. DOC was $80 \mu \mathrm{M}$ and $\mathrm{pH}$ was 8.1. All samples were stored for a maximum of 6 weeks at $4^{\circ} \mathrm{C}$. Filtered samples were obtained by passing them through a $50-\mathrm{mm}$ diameter, $0.45 \mu \mathrm{m}$ cellulose nitrate filter (Sartorius) on a Nalgene filtration unit. Subsequent filtration by a $0.02-\mu \mathrm{m}$ syringe filter yielded the ultrafiltrate. Unless stated otherwise, unfiltered samples were used.

Sunlight was simulated by a 1000-W Xe lamp (OSRAM) in a water-cooled housing (PTI, 02-A50001). The regulated power supply (PTI, LPS1000) supplied current corresponding to 50-750 W. The light was focused by two Pyrex lenses $(50 \%$ cutoff at $335 \mathrm{~nm})$ and a mirror onto a water-jacketed reactor with a quartz bottom. Alternatively, light was passed through a monochromator (PTI, 01-001, 400-nm blaze) with a $20-\mathrm{nm}$ slit before being focused by the Pyrex lenses. When the monochromator was set to 550 or $600 \mathrm{~nm}$, an additional cutoff filter $(475 \mathrm{~nm})$ was placed at its exit. A more detailed description of the general setup has been published by Siffert (1989).

We measured the average incident light intensity on the reaction vessel through a narrowband filter (UG1, $\lambda_{\max } 355$ nm) using ferrioxalate actinometry (Hatchard and Parker 1956). The total light intensity hitting the vessel, when the light was not filtered by the narrowband filter, was calculated from the photon flux of the filtered light, the transmission spectrum of the filter, and the spectrum of the unfiltered light. When a monochromator was used, direct actinometry is only adequate from $250-450 \mathrm{~nm}$, where the ferrioxalate complex absorbs the incident light. From 430 to $680 \mathrm{~nm}$ we therefore employed a LI-COR PAR sensor that had previously been calibrated for our system at $450 \pm 20 \mathrm{~nm}$ with ferrioxalate actinometry.

\section{Results}

Iron concentrations in Greifensee and Melchsee-Total iron concentrations have been determined in various lake water fractions which were separated by filtration (Table 1). We operationally define the terms "ultrafiltrate" $(<0.02$ $\mu \mathrm{m})$, "colloidal" (0.02 $\mu \mathrm{m}<x<0.45 \mu \mathrm{m})$, "filtrate" 


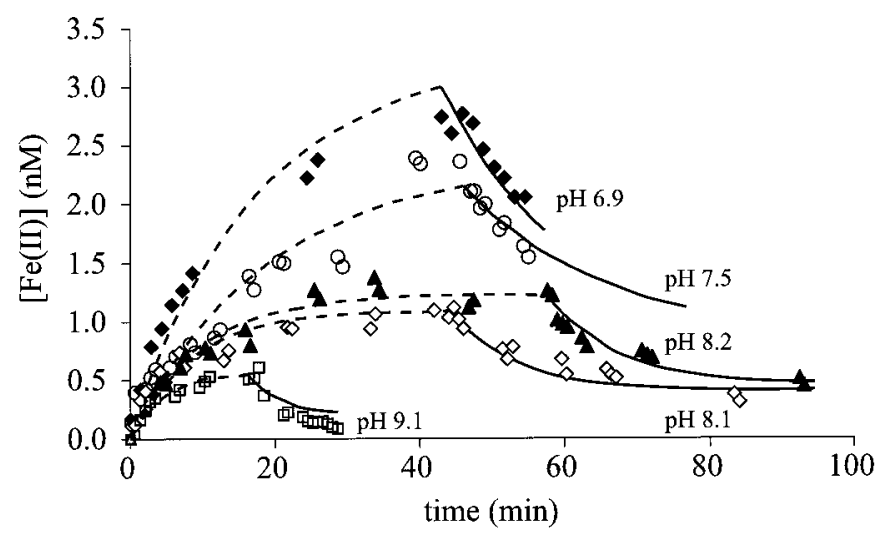

Fig. 1. Irradiation by simulated sunlight $\left(\sim 0.9 \mathrm{~kW} \mathrm{~m}^{-2}\right)$ of unfiltered samples from Greifensee. At $t=0$, irradiation was begun. Symbols are measured $\mathrm{Fe}^{\mathrm{II}}$ data, and the line is the kinetic fit. The kinetic fit is shown as a dashed line during irradiation and as a solid line when the lamp was turned off.

$(<0.45 \mu \mathrm{m})$, and "particulate" $(>0.45 \mu \mathrm{m})$. Melchsee has an iron content that is $\sim 10$ times higher for the particulate fraction, 5 times higher for the colloidal fraction, but 5 times lower in the ultrafiltrate as compared to Greifensee.

Laboratory studies of the effect of $\mathrm{pH}$ and colored dissolved organic matter (CDOM) on Fe concentration-We have irradiated unfiltered samples with simulated sunlight at various $\mathrm{pH}$ values from 6.9 to 9.1 for Greifensee and from 6.9 to 8.0 for Melchsee. The results are presented in Fig. 1 (Greifensee) and Fig. 2 (Melchsee). Fe ${ }^{\mathrm{II}}$ concentrations due to irradiation found in the two lake samples show very similar patterns. Samples from both lakes had Fe $\mathrm{Fe}^{\mathrm{II}}$ concentrations below the detection limit when kept in the dark. Irradiation by simulated sunlight rapidly produced ferrous iron. $\mathrm{Fe}^{\mathrm{II}}$ concentrations increase with decreasing $\mathrm{pH}$, as expected from the $\mathrm{pH}$ dependence of the $\mathrm{Fe}^{\mathrm{II}}$ oxidation rate. The change in $\left[\mathrm{Fe}^{\mathrm{II}}\right]$ with time becomes smaller with increasing irradiation time, and most samples reach a distinct steadystate concentration. $\mathrm{Fe}^{\mathrm{II}}$ concentrations decrease rapidly when the light is turned off, without reaching zero in the timescale of the experiments. At comparable $\mathrm{pH}$ values, steady-state concentrations are similar in water samples from the two lakes. This is in strong contrast to the observed reduction and oxidation kinetics which are markedly different in Greifensee and Melchsee.

To evaluate the impact of DOC on the concentration of $\mathrm{Fe}^{\mathrm{II}}$ under the influence of light, we have irradiated one UVtreated sample from Melchsee and compared the resulting $\mathrm{Fe}^{\mathrm{II}}$ concentrations with the values obtained with use of the corresponding untreated sample. UV-irradiation reduces $\mathrm{Fe}^{\mathrm{II}}$ steady-state concentrations by $\sim 50 \%$ (Fig. 3).

Laboratory studies on the wavelength dependence of lightinduced $\mathrm{Fe}^{I I}$ production-We have irradiated samples from Melchsee at various wavelengths and followed the production of ferrous iron. The slope of $\mathrm{Fe}^{\mathrm{II}}$ vs. time (the initial rate) is shown in Fig. 4. The quantum yield of $\mathrm{Fe}^{\mathrm{II}}$ production, however, cannot be determined, because we have no

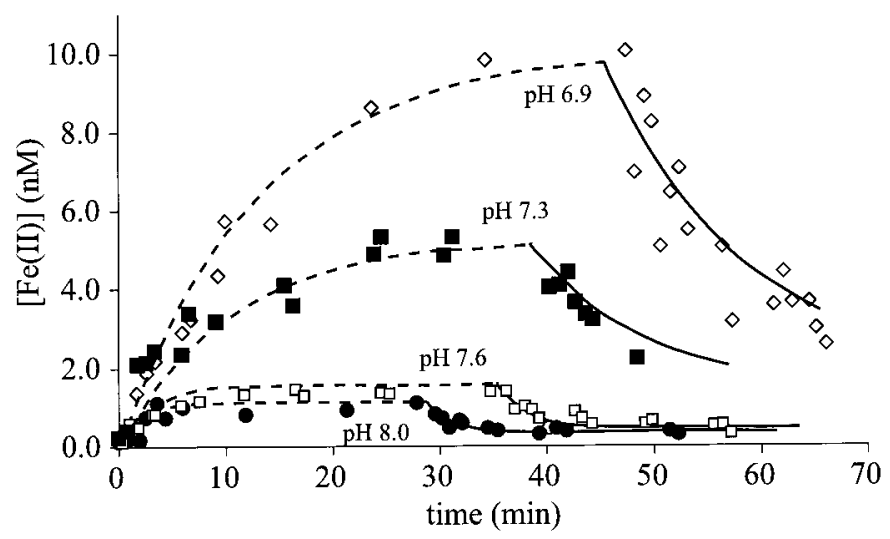

Fig. 2. Irradiation by simulated sunlight $\left(\sim 0.9 \mathrm{~kW} \mathrm{~m}^{-2}\right)$ of unfiltered samples from Melchsee. At $t=0$, irradiation was begun. Symbols are measured $\mathrm{Fe}^{\mathrm{II}}$ data, and the line is the kinetic fit. The kinetic fit is shown as a dashed line during irradiation and as a solid line when the lamp was turned off.

knowledge of the nature, concentrations, and extinction coefficients of the reactive $\mathrm{Fe}^{\mathrm{III}}$ species. Alternatively, we have normalized the initial rate of photochemical $\mathrm{Fe}^{\mathrm{II}}$ production with respect to the rate of light absorption of the water from Melchsee at wavelength $\lambda$. The normalized rate of photochemical $\mathrm{Fe}^{\mathrm{II}}$ production $R_{\mathrm{Fe}^{\mathrm{II}}, \mathrm{N}}$ is given by

$$
R_{\mathrm{Fe}^{\mathrm{II}}, \mathrm{N}}(\lambda)=\frac{R_{\mathrm{Fe}^{\mathrm{II}}}(\lambda)}{W_{\mathrm{a}}(\lambda)} .
$$

where $R_{\mathrm{Fe}^{\mathrm{II}}}(\lambda)$ is the initial rate of $\mathrm{Fe}^{\mathrm{II}}$ production and $W_{a}(\lambda)$ is the rate of light absorption by the water sample in our experimental setup:

$$
W_{\mathrm{a}}(\lambda)=\frac{1}{d} I_{0}(\lambda)\left(1-10^{-\alpha(\lambda) \cdot d}\right),
$$

where $I_{0}(\lambda)$ is the incident light intensity hitting the reaction vessel, $\alpha(\lambda)$ is the decadic molar attenuation coefficient of

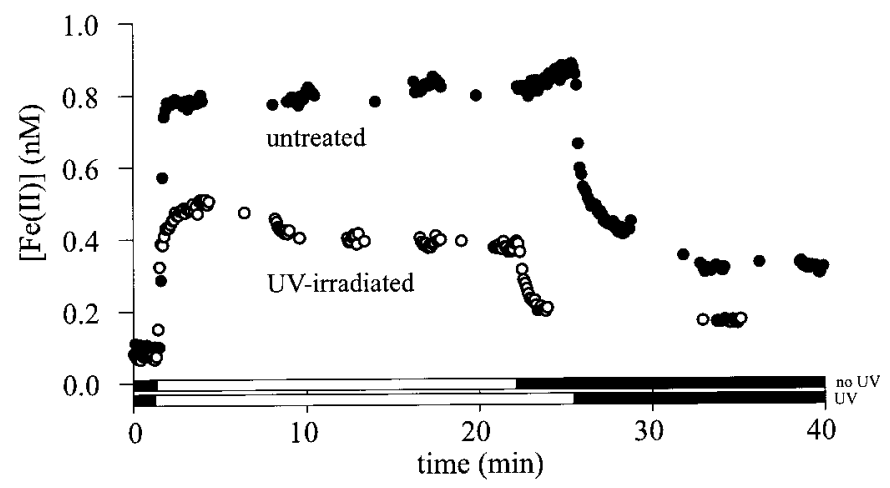

Fig. 3. Irradiation by simulated sunlight $\left(\sim 0.9 \mathrm{~kW} \mathrm{~m}^{-2}\right)$ of unfiltered water from Melchsee $(\mathrm{pH} 8.0)$ before and after UV irradiation. The bar below the $x$ axis indicates whether the light was turned on (white) or off (black). The FeLume was set to continuous mode with a time resolution of $1 \mathrm{~s}^{-1}$, and the mean values of 13 data points are shown. The standard deviation of the mean is always $<0.05 \mathrm{nM}$. Gaps in the $\mathrm{Fe}^{\mathrm{II}}$ data are due to interruptions in sampling to reduce the amount of sample needed. 


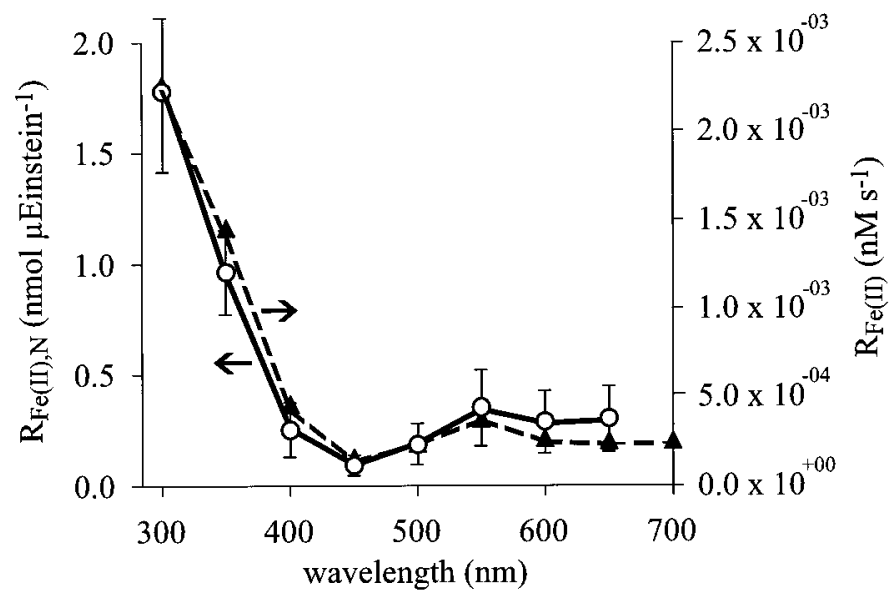

Fig. 4. Initial rate $R_{\mathrm{Fe}}$ of $\mathrm{Fe}^{\mathrm{II}}$ production (dashed line) by irradiation of samples from Melchsee (pH 7.6, 12 Dec 1998). $R_{\mathrm{Fe}^{\mathrm{II}}}$ was normalized with respect to the rate of light absorption to yield $R_{\mathrm{Fe}^{\mathrm{Il}}, \mathrm{N}}$ (solid line). The value for $R_{\mathrm{Fe}^{\mathrm{II}}, \mathrm{N}}$ at $700 \mathrm{~nm}$ was omitted because of the nonlinear response curve above $680 \mathrm{~nm}$ of the sensor used to determine incident light intensities.

the sample, and $d$ is the average light pathlength. $R_{\mathrm{Fe}^{\mathrm{II}}, \mathrm{N}}$ is highest at wavelength $<450 \mathrm{~nm}$ but is not negligible in the range $450-650 \mathrm{~nm}$.

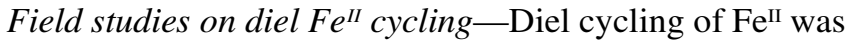
studied in field campaigns on 29 and 30 June 1998 in Greifensee and on 16 and 17 October 1998 in Melchsee. A pronounced diel cycling of $\left[\mathrm{Fe}^{\mathrm{II}}\right]$ has been observed in both lakes. In Greifensee, $\left[\mathrm{Fe}^{\mathrm{II}}\right]$ is always around the detection limit of $0.1 \mathrm{nM}$ at night, independent of depth. In the afternoon, as irradiation increases, a pronounced profile builds up from the surface down to $\sim 2 \mathrm{~m}$ depth, before [Fe $\left.{ }^{\mathrm{II}}\right]$ increases again, reaching a distinct maximum at $5 \mathrm{~m}$ (Fig. 5). Water temperature profiles (not shown) for the surface layer indicate a pronounced stratification in the afternoon of 29 June, whereas at night the water temperature was practically constant in the upper $4 \mathrm{~m}$. On the second day, 30 June, the air was not warm enough to build up a clear temperature gradient at the surface. Wind speed was low during the whole campaign $\left(<2 \mathrm{~m} \mathrm{~s}^{-1}\right)$, until the weather changed in the afternoon of 30 June, and the wind somewhat increased to 3-4 $\mathrm{m} \mathrm{s}^{-1} \cdot \mathrm{O}_{2}$ was oversaturated in the epilimnion (410 $\mu \mathrm{M})$, but its concentration started to decrease at $\sim 6.5 \mathrm{~m}$ depth, reaching $78 \mu \mathrm{M}$ at $8 \mathrm{~m}$ below the surface. The $\mathrm{pH}$ showed a typical profile due to photosynthesis in the epilimnion ( $\mathrm{pH} 8.1-8.4$ ) and decreased to $\sim 7.9$ at $10 \mathrm{~m}$ depth. Chl $a$ is available from samples taken in the afternoon of 22 June and 21 July, when Chl $a$ concentrations were between 3 and $15 \mu \mathrm{g} \mathrm{L}^{-1}$ in the epilimnion, with a pronounced maximum at 5 (June) and $7.5 \mathrm{~m}$ (July). This pattern is in good agreement with the fluorescence measured during our field campaign in the afternoon of 30 June (not shown). Hydrogen peroxide concentrations can be estimated from a series of depth profiles measured 19 and 20 July 1998 (not shown) and from the detailed data for Greifensee published by Sturzenegger (1989). We assume that $\left[\mathrm{H}_{2} \mathrm{O}_{2}\right]$ is between 20 and

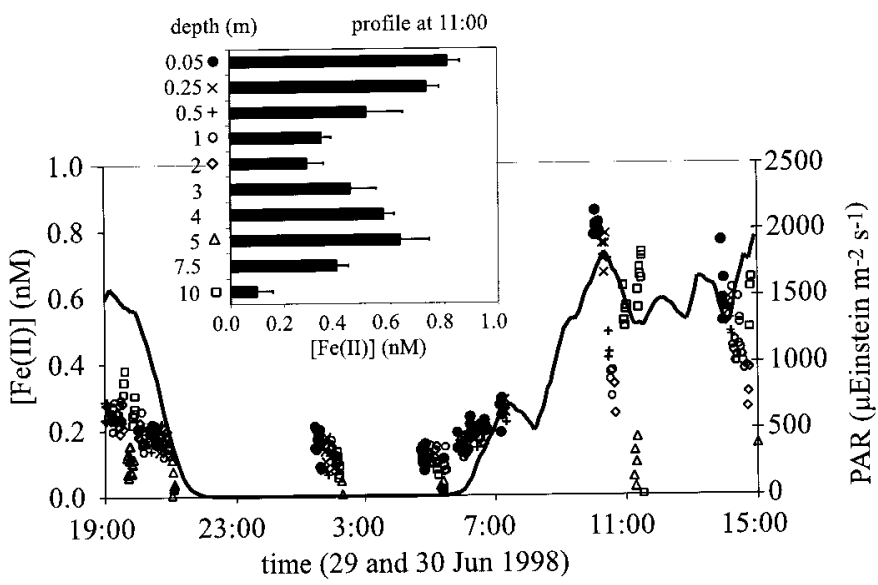

Fig. 5. Day/night cycle and depth profile in Greifensee on 29 and 30 June 1998. The solid line is irradiation as PAR. All Fe ${ }^{\mathrm{II}}$ concentrations are averages of 3-6 injections. Filled circles are concentrations found in the surface layer. The symbols placed at the $y$-axis in the inset are the legend corresponding to the main graph. Some depths are omitted for clarity. Note, that the inset profile is not at scale on the $y$ axis, to emphasize values and errors of the individual samples. The sample distribution is much more dense near the surface.

$50 \mathrm{nM}$ at night and might reach values $>500 \mathrm{nM}$ at the very surface in the afternoon of a sunny day.

The main results obtained in Melchsee on 16 and 17 October 1998 are summarized in Fig. 6, giving an overview of the data for $\left[\mathrm{Fe}^{\mathrm{II}}\right], \mathrm{PAR}$, and $\mathrm{Chl} a$. For any given depth, [Fe $\left.\mathrm{Fe}^{\mathrm{II}}\right]$ follows light intensity, leading to a pronounced day/ night cycle. At night, concentrations of $\mathrm{Fe}^{\mathrm{II}}$ are around the detection limit of $0.1-0.2 \mathrm{nM}$ throughout the water column, but as solar light intensity (measured as PAR) increases, concentrations increase and marked depth profiles appear with two characteristic maxima: one at the surface and the second

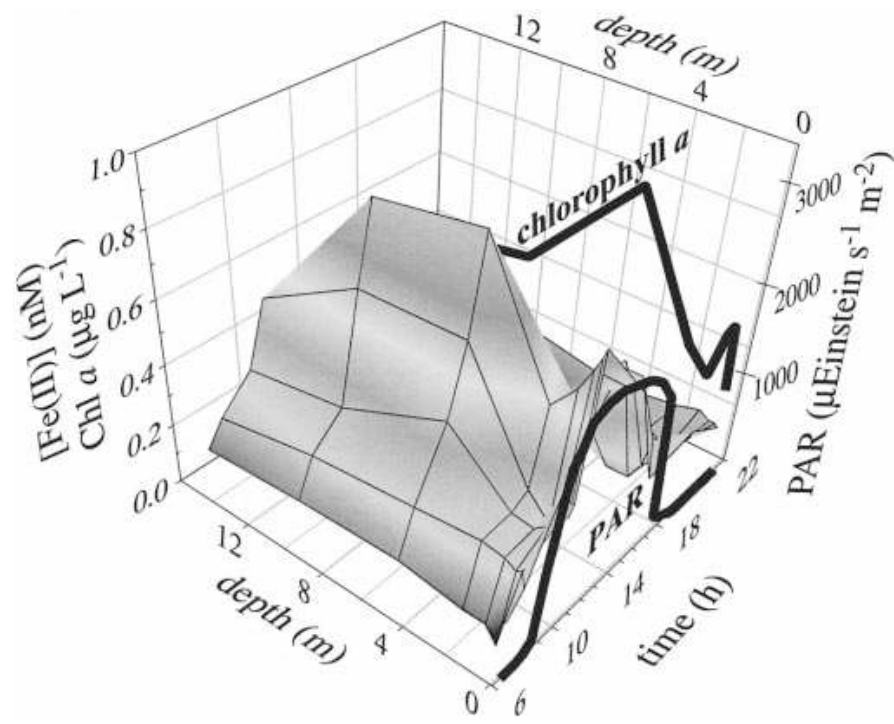

Fig. 6. Fe ${ }^{\mathrm{II}}$, PAR, and Chl $a$ as a function of time and depth in Melchsee. $\left[\mathrm{Fe}^{\mathrm{II}}\right]$ represents averages of 3-6 data points. Samples for Chl $a$ were taken at 12:00. 


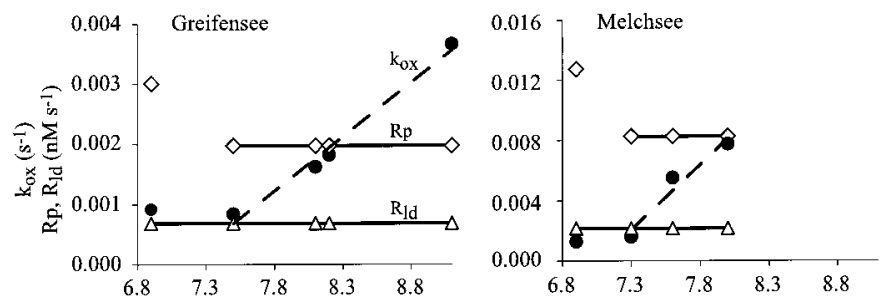

Fig. 7. Fitting parameters as a function of $\mathrm{pH} . R_{p}$, except $\mathrm{pH} 6.9$, and $R_{\mathrm{ld}}$ were set constant for all experimental data sets within one lake sample. The dashed line is a linear interpolation of $k_{\text {ox }}$ above $\mathrm{pH}$ 7.3. Rates and rate constants were obtained for samples irradiated by simulated sunlight of $\sim 0.9 \mathrm{~kW} \mathrm{~m}^{-2}$. The highest $\mathrm{pH}$ values correspond to a gas mixture containing $0 \% \mathrm{CO}_{2}$ for Greifensee and $0.5 \% \mathrm{CO}_{2}$ for Melchsee. The experiment in Melchsee water at the highest possible $\mathrm{pH}$ was interrupted because of a computer hardware problem. Note the different scales on the $y$ axis.

between 5 and $10 \mathrm{~m}$ depth. The $\left[\mathrm{Fe}^{\mathrm{II}}\right]$ profile at midday strongly resembles the $\mathrm{Chl} a$ profile. Temperature profiles measured in the evening, early morning and afternoon (not shown) indicate mixing of the epilimnion, to $\sim 4 \mathrm{~m}$ at night. Some stratification occurred in the afternoon, but gradients were small, with temperatures within $5.8^{\circ} \mathrm{C}$ and $7.5^{\circ} \mathrm{C}$ throughout the whole water column. $\mathrm{O}_{2}$ remained oversaturated to $15 \mathrm{~m}$ below the surface, and $\mathrm{pH}$ was $8.3 \pm 0.1$. The campaign was done under perfect weather conditions with no clouds and practically no wind. Air temperatures were $3^{\circ} \mathrm{C}$ at night and reached $20^{\circ} \mathrm{C}$ in the afternoon. Hydrogen peroxide showed no apparent pattern at night with concentrations between 30 and $50 \mathrm{nM}$. In the afternoon, a $\mathrm{H}_{2} \mathrm{O}_{2}$ profile built up, and at 12:30, $\left[\mathrm{H}_{2} \mathrm{O}_{2}\right]$ was already $100 \mathrm{nM}$ at the lake surface.

\section{Discussion}

Laboratory studies of the effect of $\mathrm{pH}$ and CDOM on Fe concentration-The experiments on photochemical reduction of $\mathrm{Fe}^{\mathrm{III}}$ in lake water show that samples stored in the dark for $>24 \mathrm{~h}$ have no measurable ferrous iron concentrations. However, $\left[\mathrm{Fe}^{\mathrm{II}}\right]$ increases upon irradiation and reaches a $\mathrm{pH}$ dependent steady-state concentration. For comparison of the laboratory results and to model the change in [ $\left.\mathrm{Fe}^{\mathrm{II}}\right]$ observed in field experiments, we fitted the kinetic data to obtain empirical $\mathrm{Fe}^{\mathrm{III}}$ reduction and $\mathrm{Fe}^{\mathrm{II}}$ oxidation rates. We have assumed that three processes dominate the iron redox cycle: (1) reduction of $\mathrm{Fe}^{\mathrm{III}}$ during irradiation, (2) reduction of $\mathrm{Fe}^{\mathrm{III}}$ in the dark after irradiation (in the following denoted as "light-induced dark reduction"), and (3) oxidation of $\mathrm{Fe}^{\mathrm{II}}$. The light-induced dark reduction had to be taken into account for two reasons. First, in irradiated water samples, after the light source was turned off, the disappearance of $\mathrm{Fe}^{\mathrm{II}}$ was much slower than in water samples stored in the dark for $>24 \mathrm{~h}$. Second, after the light source was turned off, $\left[\mathrm{Fe}^{\mathrm{II}}\right]$ reached a constant value above $0.3 \mathrm{nM}$ at all $\mathrm{pH}$ values, with the exception of one experiment done at $\mathrm{pH} 9.1$. Before irradiation, $\left[\mathrm{Fe}^{\mathrm{II}}\right]$ was always below the detection limit for samples stored for $>24 \mathrm{~h}$ in the dark. To model this kinetic behavior, we have introduced three parameters: $R_{p}$, overall rate of $\mathrm{Fe}^{\mathrm{III}}$ reduction under irradiation; $R_{\mathrm{ld}}$, overall

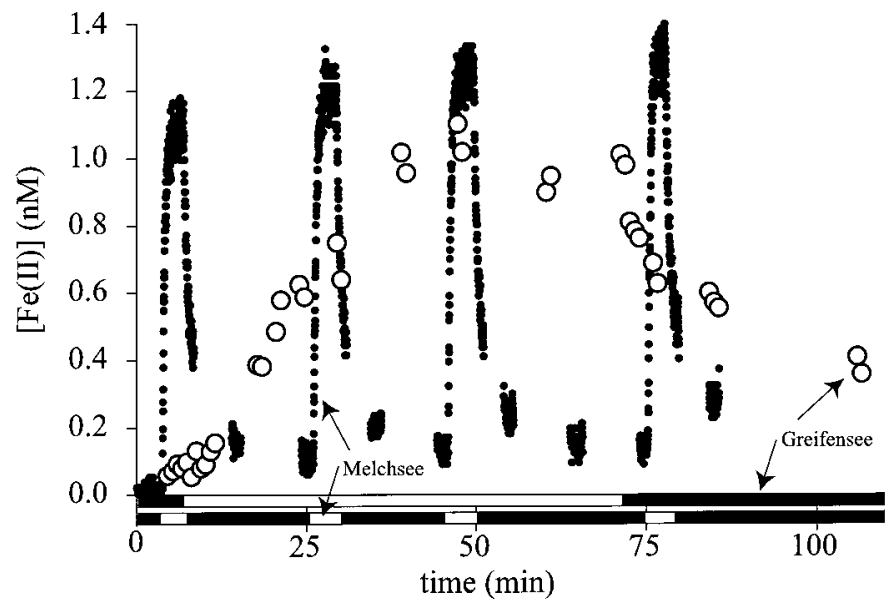

Fig. 8. Irradiation by simulated sunlight $\left(\sim 0.9 \mathrm{~kW} \mathrm{~m}^{-2}\right)$ of water from Greifensee ( $\mathrm{pH}$ 8.1) and Melchsee ( $\mathrm{pH}$ 8.0). The bar below the $x$ axis indicates whether the light was turned on (white) or off (black). For Greifensee, the FeLume was used in FIA mode and for Melchsee in continuous mode with a time resolution of $1 \mathrm{~s}^{-1}$. Gaps in the $\mathrm{Fe}^{\mathrm{II}}$ data are due to interruptions in sampling to reduce the amount of sample needed.

rate of $\mathrm{Fe}^{\mathrm{II}}$ production accounting for steady-state concentrations above zero in the dark after irradiation; and $k_{\mathrm{ox}}$, accounting for $\mathrm{Fe}^{\mathrm{II}}$ dissappearance:

$$
\frac{d\left[\mathrm{Fe}^{\mathrm{II}}\right]}{d t}=R_{p}+R_{\mathrm{ld}}-k_{\mathrm{ox}}\left[\mathrm{Fe}^{\mathrm{II}}\right]
$$

$k_{\text {ox }}$ is a net $\mathrm{Fe}^{\mathrm{II}}$ oxidation rate constant that includes both oxidation of $\mathrm{Fe}^{\mathrm{II}}$ by $\mathrm{O}_{2}$ and $\mathrm{H}_{2} \mathrm{O}_{2}$ and the light-induced dark reduction of $\mathrm{Fe}^{\mathrm{III}}$. Reductants formed upon irradiation and persisting after the light source is turned off are probably reactive oxygen species, e.g., $\mathrm{O}_{2}$ or organic peroxy radicals. All data sets for a single lake sample were modeled by use of the same values for $R_{p}$ and $R_{\mathrm{ld}}$, whereas $k_{\mathrm{ox}}$ was fitted individually for each experiment. This procedure allowed good fits for all experiments done at $\mathrm{pH}>7.3$, but the model results at $\mathrm{pH} 6.9$ were $\sim 20 \%$ too low for both Greifensee and Melchsee samples (Figs. 1 and 2). We therefore decided to treat $R_{p}$ as a free variable for the experiments done at $\mathrm{pH}$ 6.9 .

The resulting fitting parameters are given in Fig. 7 as a function of $\mathrm{pH}$. Above $\mathrm{pH} 7.4, R_{p}$ and $R_{\mathrm{ld}}$ are $\mathrm{pH}$ independent, whereas $k_{\mathrm{ox}}$ can be described as a linear function of $\mathrm{pH}$. Since $k_{\mathrm{ox}}$ comprises both oxidation and reduction processes, its $\mathrm{pH}$ dependence cannot be directly linked to a specific reaction, such as oxidation of $\mathrm{Fe}^{\mathrm{II}}$ by $\mathrm{O}_{2}$. Greifensee and Melchsee show identical patterns for the three fitting parameters, but absolute values are $\sim 4$ times higher in Melchsee than in Greifensee. This reflects the experimental observations that maximal concentrations reached in the two samples are nearly identical, whereas overall oxidation and reduction kinetics are distinctly different (Fig. 8).

The net oxidation rate constant $k_{\text {ox }}$ after irradiation can be compared with the apparent oxidation rate constant $\left(k_{\text {app }}\right)$ determined in the dark by addition of nanomolar Fe $\mathrm{F}^{\mathrm{II}}$ to Greifensee samples (Emmenegger et al. 1998). The values for 
Melchsee agree quite well with these data, but $k_{\text {ox }}$ is distinctly smaller in Greifensee after irradiation. This indicates that irradiation leads to a rapid back reaction (reduction of ferric iron) that persists after the light is turned off. In Greifensee, this back reaction seems much more pronounced (or longer lasting) than in Melchsee. It is noteworthy that $k_{\text {ox }}$ becomes invariant below $\mathrm{pH} \mathrm{7.4,} \mathrm{which} \mathrm{has} \mathrm{been} \mathrm{attributed} \mathrm{in} \mathrm{a} \mathrm{pre-}$ vious publication to the rapid oxidation of $\mathrm{Fe}^{\mathrm{II}}$ bound to unknown ligands (Emmenegger et al. 1998).

We rationalize the contrasting behavior between the two lakes by one of three hypothetical pathways: (1) rapid photolysis of reactive $\mathrm{Fe}^{\mathrm{III}}$ surface complexes dominates the photochemical reduction rate in Melchsee, whereas $R_{p}$ is determined by the reduction of dissolved $\mathrm{Fe}^{\mathrm{III}}$ by superoxide in Greifensee; (2) photolysis of dissolved Fe ${ }^{\mathrm{III}}$ complexes occurs much more efficiently in Melchsee than in Greifensee; or (3) superoxide is the main reductant for $\mathrm{Fe}^{\mathrm{III}}$ in both lakes. Lower steady-state concentrations of $\mathrm{O}_{2}^{-}$and higher concentrations of $\mathrm{Fe}^{\mathrm{III}}$ in Greifensee would then lead to similar $\left[\mathrm{Fe}^{\mathrm{II}}\right]_{\mathrm{ss}}$ but slower changes in $\left[\mathrm{Fe}^{\mathrm{II}}\right]$.

Pathway (1), photolysis of reactive Fe ${ }^{\mathrm{III}}$ surface complexes, can be invoked because there is a striking difference in iron content between the two lakes, which might explain the different kinetics of light-induced $\left[\mathrm{Fe}^{\mathrm{II}}\right]$; Melchsee hascompared with Greifensee-an iron content that is $\sim 10$ times higher for the particulate fraction and 5 times higher for the colloidal fraction (see Table 1). To test whether reactions with particulate or colloidal Fe species are dominating $\mathrm{Fe}^{\mathrm{III}}$ reduction in Melchsee, we irradiated unfiltered, filtered, and ultrafiltered samples with artificial sunlight at $\mathrm{pH}$ 7.6 (data not shown). Irradiation led to a rapid increase of ferrous iron, reaching a plateau at $\sim 1.2-1.4 \mathrm{nM}$ after $20-30$ min. Ferrous iron decreased rapidly when the light was turned off. There was, however, no significant difference in steady-state $\left[\mathrm{Fe}^{\mathrm{II}}\right]$ in unfiltered, filtered, and ultrafiltered samples within the experimental errors. The ultrafiltrate contains no minerals, colloids or microorganisms, and its iron content is $<2 \%$ of the unfiltered sample. These results clearly disagree with pathway (1).

One might expect further evidence to distinguish between pathways (2) and (3) from the results for an UV-irradiated sample that indicate that CDOM plays an important role in the light-induced production of ferrous iron (Fig. 3). However, both the formation of photochemically reactive $\mathrm{Fe}^{\mathrm{III}}$ (surface) complexes and the production of $\mathrm{O}_{2}^{--}$are likely to depend on CDOM.

Laboratory studies on the wavelength dependence of lightinduced $\mathrm{Fe}^{\text {II }}$ production-The wavelength dependence is important for two main reasons. First, it can give us further clues to determine the dominating pathway for $\mathrm{Fe}^{\mathrm{III}}$ reduction. And, second, it is necessary to evaluate the $\mathrm{Fe}^{\mathrm{II}}$ production within the water column, because the penetration depth of light is strongly dependent on $\lambda$. Figure 4 shows a very similar pattern for the initial rate $R_{\mathrm{Fe}}$ and the normalized initial rate $R_{\mathrm{Fe}^{\mathrm{II}}, \mathrm{N}}$. This indicates a relatively even distribution of the rate of light absorption over the whole light spectrum; the high absorption coefficients $\alpha(\lambda)$ of the sample below $400 \mathrm{~nm}$ are largely compensated by low photon emission rates of the light source in this range of the spectrum.
Below $450 \mathrm{~nm}$, complexes of ferric iron with small organic ligands or with humic substances have pronounced absorption bands, and oxidation of organic ligands by ligand-to-metal charge-transfer reactions has been repeatedly suggested (Waite and Morel 1984; Voelker et al. 1997). Photolysis of inorganic $\mathrm{Fe}^{\mathrm{III}}$ complexes can also be expected in this wavelength range, because various inorganic Fe $\mathrm{Fe}^{\mathrm{III}}$ species, including hydroxides, absorb light below $450 \mathrm{~nm}$, and $\mathrm{Fe}(\mathrm{OH})^{2+}$ has been shown to be the most important chromophore responsible for inorganic $\mathrm{Fe}^{\mathrm{III}}$ photoreduction (King et al. 1993). Alternatively, $\mathrm{Fe}^{\mathrm{III}}$ may also be reduced by superoxide that is photochemically produced through electron transfer to $\mathrm{O}_{2}$ from CDOM in its triplet state (Blough and Zepp 1995).

Above $450 \mathrm{~nm}$, complexes of ferric iron have usually only weak absorption bands. Certain $\mathrm{Fe}^{\mathrm{III}}$ siderophore complexes, nevertheless, absorb light far into the visible region (Albrecht-Gary and Crumbliss 1998). To our knowledge, however, direct photoreduction of such complexes has not yet been demonstrated. Poly Fe ${ }^{\mathrm{III}}$ hydroxo complexes might also absorb visible light and undergo photochemical reduction. Polymerization tends to shift the range of absorbed light to higher wavelengths. The $\mathrm{Fe}^{\mathrm{III}}$ dimer, $\mathrm{Fe}_{2}(\mathrm{OH})_{2}{ }^{4+}$ has been shown to absorb light in the visible range (up to $\sim 450 \mathrm{~nm}$ ) and to photolyze, producing $\mathrm{OH}^{\cdot}$ radicals (Knight and Sylva 1975).

An alternative process for the reduction of ferric iron by light of wavelength $>450 \mathrm{~nm}$ might involve the formation of reactive intermediates. A number of naturally occurring pigments are known to act as photosensitizing dyes, producing singlet oxygen when submitted to light above $500 \mathrm{~nm}$ (Larson 1978), and quantum yields of ${ }^{1} \mathrm{O}_{2}$ production by humic materials have been published by Haag et al. (1984). Chl $a$, for example has a pronounced second absorption maximum between 600 and $700 \mathrm{~nm}$. Upon light absorption, it can form an excited triplet state through intersystem crossing and then react with ${ }^{3} \mathrm{O}_{2}$ to form ${ }^{1} \mathrm{O}_{2}$ (Tevini and Häder 1985). It is conceivable that singlet oxygen would form superoxide, which could then reduce inorganic Fe $\mathrm{Fe}^{\mathrm{III}}$. The formation of $\mathrm{O}_{2}^{--}$has been proposed by Tratnyek and Hoigné (1994) in the oxidation of 2,4,6-trimethylphenol by ${ }^{1} \mathrm{O}_{2}$. Superoxide is furthermore generated enzymatically by a number of proteins such as xanthine oxidase (Larson 1978). This may be another indirect source of $\mathrm{Fe}^{\mathrm{II}}$ production by light from the visible part of the spectrum. The spectral region above $450 \mathrm{~nm}$ is important for the depth-integrated $\mathrm{Fe}^{\mathrm{II}}$ production, because the penetration depth of solar radiation increases with increasing wavelengths.

The wavelength dependence of $\mathrm{Fe}^{\mathrm{II}}$ production does not clearly distinguish between pathways (2) and (3). However, the mechanisms described above seem to favor the formation of reactive intermediates, which is consistent with pathway (3), the assumption that superoxide is a dominant factor in the light-induced iron redox cycle.

Modeling of laboratory experiments-To further evaluate the reaction pathways determining $\mathrm{Fe}^{\mathrm{II}}$ concentrations under the different lake conditions, we attempt to simulate the data shown in Fig. 8 with kinetic modeling. In particular, we used this approach to elucidate whether known reactions with su- 
Table 2. Reactions and rate constants or rates used in the kinetic model.

\begin{tabular}{|c|c|c|c|}
\hline No. & Equation & $k\left(\mathrm{M}^{-1} \mathrm{~s}^{-1}\right)$ & Reference \\
\hline 1 & $\mathrm{Fe}^{\mathrm{III}}+\mathrm{O}_{2}^{-} \rightarrow \mathrm{Fe}^{\mathrm{II}}+\mathrm{O}_{2}$ & $1.50 \times 10^{8}$ & Rush and Bielski 1985* \\
\hline 2 & $\mathrm{Fe}^{\mathrm{II}}+\mathrm{O}_{2} \rightarrow \mathrm{Fe}^{\mathrm{III}}+\mathrm{O}_{2}^{-}$ & 19.7 (Gsee), 12.3 (Msee) & King $1998 \dagger$ \\
\hline 3 & $\mathrm{Fe}^{\mathrm{II}}+\mathrm{O}_{2}^{-} \rightarrow \mathrm{Fe}^{\mathrm{III}}+\mathrm{H}_{2} \mathrm{O}_{2}$ & $1.00 \times 10^{7}$ & Rush and Bielski $1985 \ddagger$ \\
\hline 5 & $\mathrm{O}_{2}^{-}+\mathrm{O}_{2}^{-}+2 \mathrm{H}^{+} \rightarrow \mathrm{H}_{2} \mathrm{O}_{2}+\mathrm{O}_{2}$ & $\log (\mathrm{k})=12.7-1.0(\mathrm{pH})$ & Zafiriou 1990 \\
\hline 6 & $\mathrm{Cu}^{\mathrm{II}}+\mathrm{O}_{2}^{-} \rightarrow \mathrm{Cu}^{\mathrm{I}}+\mathrm{O}_{2}$ & $2.93 \times 10^{9}$ & $\begin{array}{l}\text { Estimated from Zafiriou et al. } 1998 \\
\text { and von Piechowski et al. 1993प }\end{array}$ \\
\hline 9 & $\mathrm{CDOM}+\mathrm{O}_{2}+\mathrm{hv} \rightarrow \mathrm{CDOM}^{+}+\mathrm{O}_{2}^{-}$ & Fitting parameter & \\
\hline
\end{tabular}

* For inorganic, dissolved $\mathrm{Fe}^{\mathrm{III}}$ at $\mathrm{pH}>6$.

$\dagger$ Rate constant given by King (1998) for $I=0$, corrected for $I=7 \mathrm{mM}$, using Debye Hückel. Greifensee (Gsee): alkalinity $=3.9 \mathrm{mM}$, pH $=8.0 ; \mathrm{Melchsee}$ (Msee): alkalinity $=1.4 \mathrm{mM}, \mathrm{pH}=8.1$.

$\ddagger$ For inorganic, dissolved $\mathrm{Fe}^{\mathrm{II}}$ at $\mathrm{pH}>6$.

$\S$ Rate constant given by King and Farlow (2000) for $I=0$, corrected for $I=7 \mathrm{mM}$ by use of Debye Hückel. Greifensee: alkalinity $=3.9 \mathrm{mM}$, $\mathrm{pH}=8.0$; Melchsee: alkalinity $=1.4 \mathrm{mM}, \mathrm{pH}=8.1$. Regarding $\mathrm{HO}$ as a potential oxidant of $\mathrm{Fe}^{\mathrm{II}}$, we can neglect this pathway in these lake water samples on the basis of a previous study (Emmenegger et al. 1998). We have also neglected that products of reactions of HO with other lakewater components, e.g., $\mathrm{CO}_{3}^{2-}$, might-directly or indirectly-affect the iron redox cycle.

II The value of this rate constant was calculated as follows: $k=\alpha_{\mathrm{CuCO}_{3}} k_{\mathrm{CuCO}_{3}}+\alpha_{\mathrm{Cu}^{2}} k_{\mathrm{Cu}^{2+}}$, where $\alpha_{\mathrm{CuCO}_{3}}$ and $\alpha_{\mathrm{Cu}^{2+}}$ were assumed to be 0.95 and 0.05 , respectively, and values for $k_{\mathrm{CuCO}_{3}}$ and $k_{\mathrm{Cu}^{2+}}$ are taken from Zafiriou et al. (1998) and von Piechowski et al. (1993), respectively; see also text.

\# Rate assumed in the same range as that suggested by Miller et al. (1995); see also text.

peroxide are consistent with the laboratory experiments. The setup was treated as a fully mixed reactor in the simulation tool Aquasim (Reichert 1994), with reactions and rate constants or rates as summarized in Table 2. The rate constants of reactions 1-7 were taken from the literature, and the rate of reaction 8 was assumed to be in the range suggested by Miller et al. (1995). The rate constant of the CDOM sensitized $\mathrm{O}_{2}^{-}$production (reaction 9 ) was a fitting parameter in our model. $\left[\mathrm{Fe}^{\mathrm{III}}\right],[\mathrm{Cu}]_{\text {inorg }}$, and $\left[\mathrm{Fe}^{\mathrm{III}}-\mathrm{L}\right]$ are poorly known in our system and have, therefore, also been considered as fitting parameters. The latter two, however, were only included if this significantly improved the agreement between model and experimental data.

The following values and boundaries were used as the model input data: $\left[\mathrm{Fe}^{\mathrm{III}}\right]$ stands for the concentration of inorganic dissolved ferric iron that has not been directly measured. We used values of [ $\left.\mathrm{Fe}^{\mathrm{III}}\right]$ between $10^{-8}$ (oversaturated) and $10^{-10} \mathrm{M}$. Furthermore, we assumed $\mathrm{Fe}^{\mathrm{III}}$ to be continuously regenerated and set its concentration constant. [ $\mathrm{Fe}^{\mathrm{III}}-$ L] represents the concentration of dissolved organic $\mathrm{Fe}^{\mathrm{III}}$ complexes and poly $\mathrm{Fe}^{\mathrm{III}}$ hydroxo complexes. Photolysis of these complexes (reaction 8) was only included in the model if this significantly improved the agreement between model and experimental data. For $\mathrm{H}_{2} \mathrm{O}_{2}$ there are other sinks and possibly also other sources than those included in the model, such as biological decomposition (Petasne and Zika 1987). We have, therefore, used the experimentally determined net production rate of $170 \mathrm{nM} \mathrm{h}^{-1}$ in an unfiltered sample, from Melchsee, irradiated at $\mathrm{pH} 8.0$ with $0.9 \mathrm{~W} \mathrm{~m}^{-2}$ of simulated sunlight. This is in good agreement with the values given for Greifensee by Sturzenegger (1989).

Furthermore, we have considered reactions of $\mathrm{O}_{2}^{--}$with inorganic, dissolved copper species (Sedlak and Hoigné 1993; von Piechowski et al. 1993; Zafiriou et al. 1998). These reactions (reactions 6 and 7) were, however, only included if they significantly improved the agreement between model and experimental data. In Greifensee, total dissolved copper concentrations are $1-3 \times 10^{-8} \mathrm{M}$, of which $\sim 99 \%$ is organically complexed (Xue et al. 1995). Inorganic, dissolved copper in Greifensee is in the range $10^{-14}-10^{-12} \mathrm{M}$, on the basis of calculated values of free copper (Xue et al. 1995). Although the total dissolved copper concentration is probably smaller in Melchsee than in Greifensee, the concentration of dissolved inorganic copper is likely to be at least as high as in Greifensee because of the much smaller DOC content in Melchsee. We have, therefore, set $[\mathrm{Cu}]_{\text {inorg }}$ $<10^{-10} \mathrm{M}$. Note that $[\mathrm{Cu}]_{\text {inorg }}$, the rate constant of $\mathrm{O}_{2}^{--}$reaction with inorganic copper, and the rate of CDOM sensitized $\mathrm{O}_{2}^{-}$production are interdependent, regarding $\mathrm{O}_{2}^{-}$ steady-state concentrations. However, these three parameters have to be invoked independently, to simulate simultaneously $\mathrm{Fe}^{\mathrm{II}}$ steady-state concentrations and the kinetics of $\mathrm{Fe}^{\mathrm{II}}$ formation and consumption. As to the speciation of inorganic, dissolved copper in these lakes, most of $\mathrm{Cu}^{\mathrm{I}}$ can be assumed to be present as $\mathrm{Cu}^{+}, \sim 95 \%$ of $\mathrm{Cu}^{\mathrm{II}}$ as $\mathrm{CuCO}_{3}$, and $\sim 5 \%$ as $\mathrm{Cu}^{2+}$. We have used rate constants available from the literature for reaction of these copper species with $\mathrm{O}_{2}^{-}$ (see comments of Table 2).

As seen in Figs. 9 and 10, excellent agreement between model and data was obtained, without taking into account photolysis of Fe $\mathrm{Fe}^{\mathrm{III}}$ complexes, for both Greifensee and Melchsee water. This is a further indication that reduction of $\mathrm{Fe}^{\mathrm{III}}$ by $\mathrm{O}_{2}^{-}$is the main source of $\mathrm{Fe}^{I I}$ in these lakes. The model results yield a concentration of inorganic dissolved $\mathrm{Fe}^{\mathrm{III}}$ that is lower, by a factor of five, in Melchsee than in Greifensee. This agrees with the fact that the concentration of iron in the ultrafiltrate is about five times smaller in Melchsee than in Greifensee (see Table 1). According to the model results, $\left[\mathrm{Fe}^{\mathrm{III}}\right]$ is much smaller than the $\mathrm{Fe}^{\mathrm{II}}$ steadystate concentration reached upon irradiation. This implies a source of inorganic dissolved $\mathrm{Fe}^{\mathrm{III}}$ other than $\mathrm{Fe}^{\mathrm{II}}$ oxidation, possibly weakly organically complexed $\mathrm{Fe}^{\mathrm{III}}$ and/or poly $\mathrm{Fe}^{\mathrm{III}}$ 


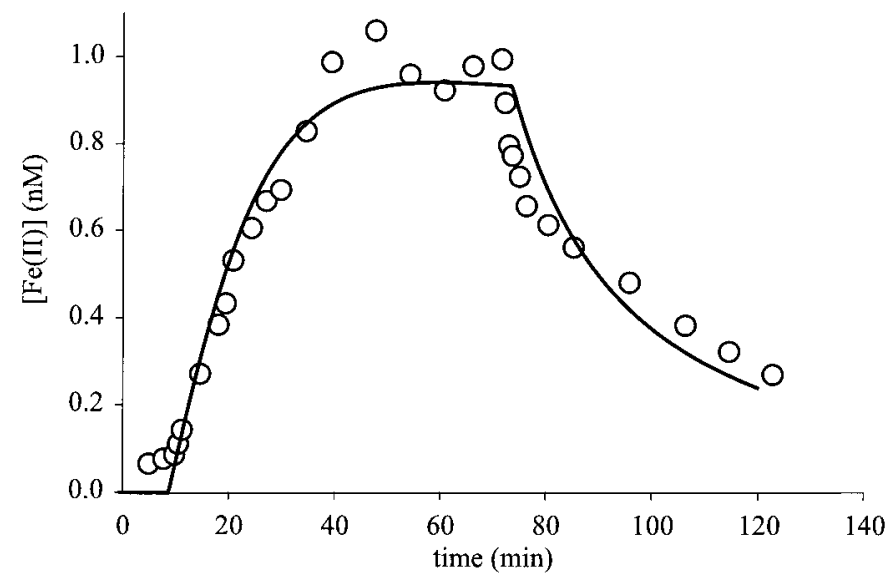

Fig. 9. Greifensee, experimental data and modeling results. Best fit is obtained for $\left[\mathrm{Fe}^{\mathrm{III}}\right]=0.5 \mathrm{nM}$ and $k_{9}=10^{-12} \mathrm{M} \mathrm{s}^{-1} . \mathrm{Cu}-$ catalyzed dismutation $\left(k_{6}\right.$ and $\left.k_{7}\right)$ or photolysis of $\mathrm{Fe}^{\mathrm{III}}-\mathrm{L}\left(k_{8}\right)$ are not necessary to model the system. $\left[\mathrm{O}_{2}^{-}\right]$is mainly produced by reaction 9 , and its concentration is controlled by iron redox cycling (reactions $1-4$ ) yielding $\left[\mathrm{O}_{2}^{-}\right]_{\mathrm{ss}}$ of $\sim 0.05 \mathrm{nM}$.

hydroxo complexes contained in the iron pool that passes a $0.02-\mu \mathrm{m}$ filter. The simulation furthermore suggests that the rate of $\mathrm{O}_{2}^{--}$production is a factor of 100 higher in Melchsee than in Greifensee and in the same order of magnitude as $\mathrm{O}_{2}^{-}$formation estimated for coastal seawater (Micinski et al. 1993) for the ambient ionic strength of Melchsee. The much smaller estimated $\mathrm{O}_{2}^{--}$formation rate in Greifensee may be due to the fact that these are net rates including additional sinks for $\mathrm{O}_{2}^{-}$, which we have not considered in our model. In Greifensee, additional sinks could be reaction of $\mathrm{O}_{2}^{--}$with organic copper complexes (Voelker et al. 2000) and possibly reaction of $\mathrm{O}_{2}^{--}$with CDOM (Goldstone and Voelker 2000). (Note that for Greifensee water, the agreement between model and experimental data was obtained without considering reactions of $\mathrm{O}_{2}^{--}$with inorganic dissolved copper; see Fig. 9.) The different rates of $\mathrm{O}_{2}^{-}$formation in Greifensee and Melchsee could also be due to different origins and chemical composition of CDOM in the two lakes.

We have made numerous assumptions in developing a model that simulates the experimentally determined $\mathrm{Fe}^{\mathrm{II}}$ concentration versus time courses during and after irradiation in water samples from Greifensee and Melchsee. Concentrations of reactants, as well as rate constants or rates that served as input parameters are subject to large uncertainties. We must, therefore, stress that this is not a predictive model that can be applied to other lake systems. The main purpose of the model is to serve as a tool for exploring the influence of the various reactions involved in determining $\mathrm{Fe}^{\mathrm{II}}$ concentrations in Greifensee and Melchsee. This approach yields reasonable results that-if used with the necessary caution-significantly enhance our understanding of the light-induced redox cycling of iron in freshwater.

Field studies on diel Fe $\mathrm{F}^{I I}$ cycling-The pattern of $\mathrm{Fe}^{\mathrm{II}}$ concentrations as a function of depth and time are very similar in Melchsee and Greifensee. For any given depth, [Fe"I follows incident light intensity, leading to a pronounced day/

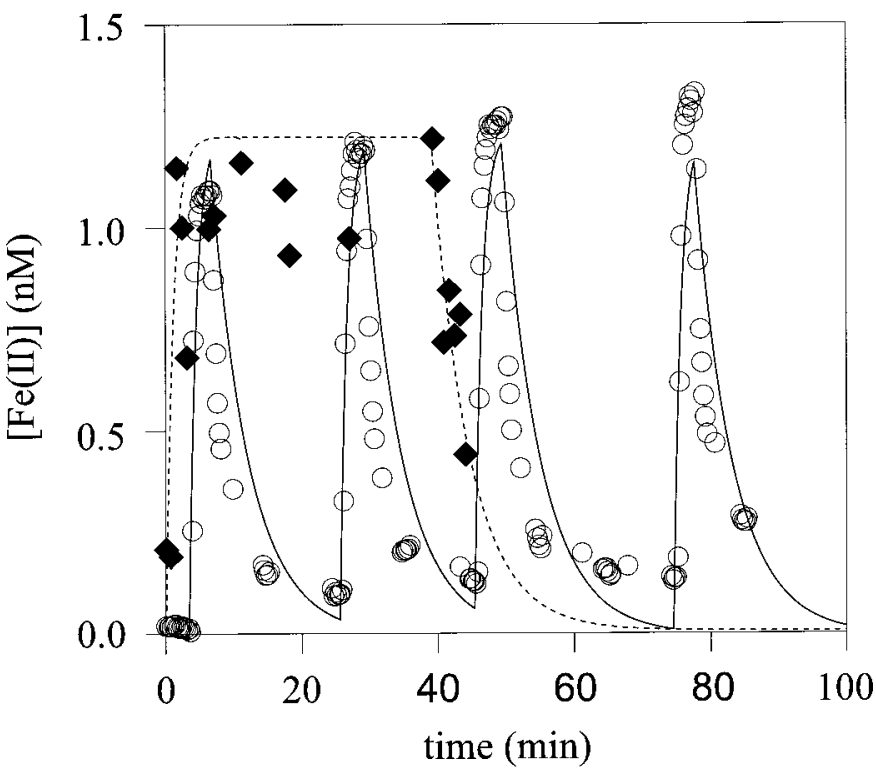

Fig. 10. Melchsee, experimental data and and modeling results. One additional experiment was added to the data set shown in Fig. 8 to stress that $\left[\mathrm{Fe}^{\mathrm{II}}\right]$ in Melchsee remains at the rapidly reached steady state for the timescale of the experiment. Best fit is obtained for $\mathrm{Cu}^{\mathrm{I}}+\mathrm{Cu}^{\mathrm{II}} \approx 10^{-10} \mathrm{M},\left[\mathrm{Fe}^{\mathrm{III}}\right] \approx 0.1 \mathrm{nM}$, and $k_{9} \approx 10^{-10} \mathrm{M} \mathrm{s}^{-1}$. The model suggests that $\left[\mathrm{O}_{2}^{-}\right]$is mainly produced by reaction 9 and consumed by copper-catalyzed dismutation yielding $\left[\mathrm{O}_{2}^{-}\right]_{\mathrm{ss}}$ of $\sim 1$ nM. Photolysis of $\mathrm{Fe}^{\mathrm{III}}-\mathrm{L}\left(k_{8}\right)$ is not necessary to model the system.

night cycle. At night, concentrations of $\mathrm{Fe}^{\mathrm{II}}$ are around the detection limit of $0.1-0.2 \mathrm{nM}$ throughout the water column, but, as solar light intensity (measured as PAR) increases, $\mathrm{Fe}^{\mathrm{II}}$ concentrations increase, and marked depth variations appear with two characteristic maxima: one at the surface and the second at $\sim 5 \mathrm{~m}$ depth.

Oxygen concentration and $\mathrm{pH}$ strongly influence the redox cycle and must be considered when interpreting this deeper maximum. In Greifensee, $\mathrm{pH}$ is 8.4 between 0.5 and $2 \mathrm{~m}$, decreasing to 7.9 at $10 \mathrm{~m}$ depth. Oxygen concentrations also diminish markedly below $6.5 \mathrm{~m}$. At lower $\mathrm{pH}$ and reduced $\left[\mathrm{O}_{2}\right], \mathrm{Fe}^{\mathrm{II}}$ oxidation becomes slower, which leads to increased $\left[\mathrm{Fe}^{\mathrm{II}}\right]$. This does, however, not explain the measured [ $\left.\mathrm{Fe}^{\mathrm{II}}\right]$ depth profile, as will be shown by the modeling below. Furthermore, the $\left[\mathrm{Fe}^{\mathrm{II}}\right]$ pattern with two maxima can also be found in Melchsee, despite its $\mathrm{O}_{2}$ saturation and nearly constant $\mathrm{pH}$ throughout the water column.

We suggest that these profiles should be interpreted by considering two layers that are dominated by different mechanisms. In the upper layer, from the surface to $\sim 2 \mathrm{~m}$ depth, photochemically induced reduction of $\mathrm{Fe}^{\mathrm{III}}$ creates a $\left[\mathrm{Fe}^{\mathrm{II}}\right]$ profile that reflects the decreasing light intensity with depth due to light absorption by all the light-absorbing components in lake water. The deeper maximum of $\left[\mathrm{Fe}^{\mathrm{II}}\right]$, below $3 \mathrm{~m}$ depth, cannot be explained solely by photochemical processes. At this depth- $5 \mathrm{~m}$ for Greifensee and between 5 and $10 \mathrm{~m}$ in Melchsee-light intensity is $<5 \%$ for PAR and $<1 \%$ of the incident light for UVA and UVB.

The pronounced similarity with $\mathrm{Chl} a$ concentrations indicates that the deeper $\mathrm{Fe}^{\mathrm{II}}$ maximum is linked to biological 

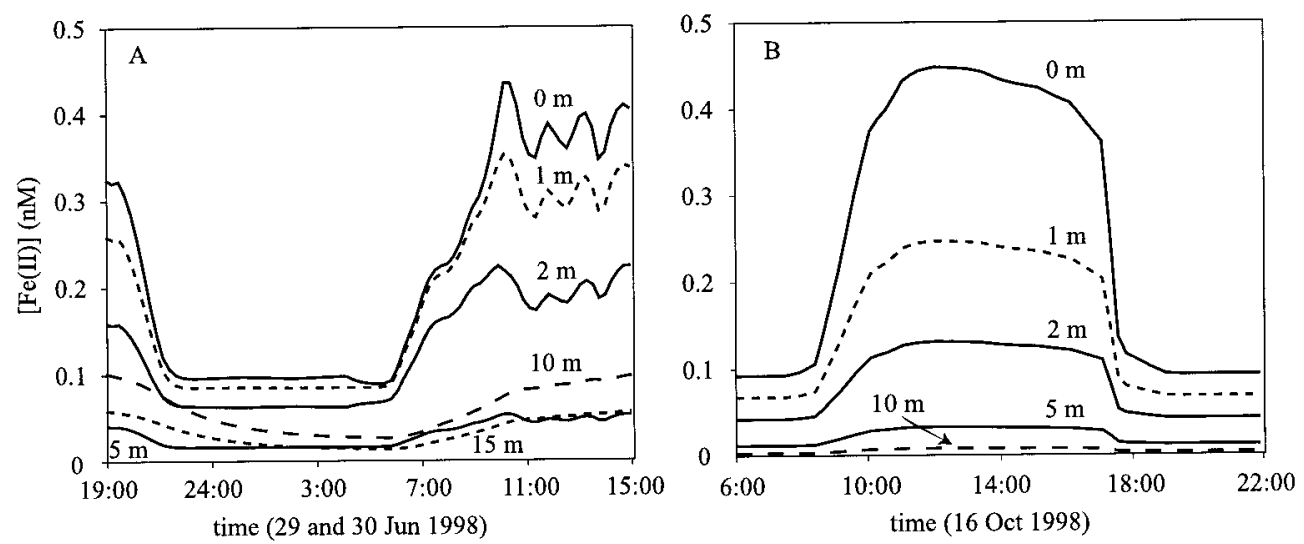

Fig. 11. Modeled $\mathrm{Fe}^{\mathrm{II}}$ concentrations in $(A)$ Greifensee and $(B)$ Melchsee. Initial conditions were approximated by starting the simulation with $\left[\mathrm{Fe}^{\Pi}\right]=0$ one day before the beginning of the field campaign. The displayed time range corresponds to the field data shown in Fig. 5 (Greifensee) and Fig. 6 (Melchsee).

processes. The observed association of $\left[\mathrm{Fe}^{\mathrm{II}}\right]$ with sunlight can then be explained either directly by the light dependent activity of microorganisms or by the enhancement of lightinduced $\mathrm{Fe}^{\mathrm{III}}$ reduction due to biological processes. Although the identification of such mechanisms was not the main focus of the present study, we will point to some pathways that, under oxic conditions, could explain our observations: Reduction of $\mathrm{Fe}^{\mathrm{III}}$ at cell surfaces (Jones et al. 1987; Price and Morel 1990); or secretion of organic Fe ${ }^{\mathrm{III}}$ ligands forming complexes that are readily photolyzed could lead to enhanced $\left[\mathrm{Fe}^{\mathrm{II}}\right]$. Photolysis of simple complexes such as $\mathrm{Fe}^{\mathrm{III}}$ oxalate, malonate, and citrate have been widely studied (Faust and Zepp 1993). In addition, release of (inorganic or organic) $\mathrm{Fe}^{\mathrm{III}}$ species that are readily reduced under the influence of light might increase [Fe" $\left.{ }^{\mathrm{II}}\right]$. Certain iron colloids can be transformed by digestion in acidic food vacuoles of protozoan grazers into a form that is more bioavailable than refractory phases (Barbeau et al. 1996). It is conceivable that such mechanisms also increase the fraction of photochemically labile (colloidal) iron species. Finally, secretion of (organically complexed) $\mathrm{Fe}^{\mathrm{II}}$ by bacteria or phytoplankton due to cell lysis could be a factor. Some of the microbial iron, for example in cytochromes, will always be in its reduced form. Exudates and lysates can, therefore, contain $\mathrm{Fe}^{\mathrm{II}}$, which would be oxidized in the epilimnion with a rate that depends on the type of $\mathrm{Fe}^{\mathrm{II}}$ complex.

Modeling of field data-In order to further evaluate the processes controlling $\mathrm{Fe}^{\mathrm{II}}$ concentrations, we have simulated $\left[\mathrm{Fe}^{\mathrm{II}}\right]$ in the lakes as a function of both time and depth. This was done by including the kinetic data from laboratory studies and the measured field data in a model, which was implemented as a lake compartment in Aquasim (Reichert 1994). This link between the work done in the laboratory and values obtained in the field gives us additional information about the quality of the data obtained and the sensitivity of the natural system with respect to the various parameters used.

For modeling, the incident light intensity was calculated from measured depth profiles (UVA, UVB, and PAR) and continuous measurement of PAR at the surface during the sampling campaigns. The photochemical reduction rate $R_{\mathrm{Fe}}(\Delta \lambda)$ was then estimated as a function of light intensity for any depth and $\Delta \lambda=$ UVA, UVB, or PAR (Emmenegger

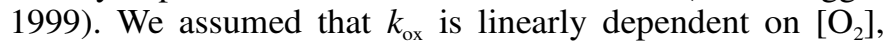
which decreased significantly with depth in Greifensee. Measured depth profiles for $\mathrm{pH}$ and $\left[\mathrm{O}_{2}\right]$ were used as input data for the model and considered to be constant during the field campaign. The dark reduction rate, $R_{\mathrm{ld}}$, was considered to be constant with time. However, since $R_{\mathrm{ld}}$ is light-induced (no measurable $\left[\mathrm{Fe}^{\mathrm{II}}\right]$ is found when samples are stored in the dark) we assumed that $R_{\mathrm{ld}}$ for each depth is proportional to its respective light intensity at midday. Turbulent mixing was described by a coefficient of vertical turbulent diffusion, $K_{Z}$, which we estimated for Greifensee by using the $k-e$ modeling technique, as described by Goudsmit and Wüest (1999). This procedure allows the calculation of $K_{Z}$ as a function of time and depth on the basis of surface heat fluxes and wind speed. It is especially suited for determining $K_{Z}$ in surface layers, where vertical diffusion largely depends on interactions at the surface boundary. Values for $K_{Z}$ were between $3 \times 10^{-3}$ and $10^{-7}$, which is typical for the summer season on a day with little wind. Since the simulations were not very sensitive to $K_{Z}$ for clear skies and low windspeed, we used a constant $K_{Z}$ of $10^{-3}$ for the field campaign on Melchsee.

The main results of the lake simulations are shown in Fig. 11. The time frame chosen for these graphs corresponds to the field data shown in Figs. 5 and 6. The modeled FeII concentrations follow light intensity very closely, confirming that the processes determining [ $\left.\mathrm{Fe}^{\mathrm{II}}\right]$ are faster than variations in sunlight intensity. $\mathrm{Fe}^{\mathrm{II}}$ concentrations decrease rapidly with depth, illustrating that the only source of ferrous iron in our model is the light-induced reduction of $\mathrm{Fe}^{\mathrm{III}}$. In Greifensee, a small increase of $\left[\mathrm{Fe}^{\mathrm{II}}\right]$ occurs between 5 and 10 $\mathrm{m}$, which is due to the pronounced consumption of $\mathrm{O}_{2}$ in the layer below $6 \mathrm{~m}$. The calculated concentrations match the measured field data within a factor of 2, which is remarkable, given the uncertainty of the used rate constants and the various assumptions made.

The second $\mathrm{Fe}^{\mathrm{II}}$ peak, which correlates with $\mathrm{Chl} a$ concentrations, is not described by the model. This is not sur- 
prising, because the photochemical experiments, which we used to supply the main rates and rate constants for the simulation, would not have shown biologically induced $\mathrm{Fe}^{\text {II. The }}$ simulation results, therefore, reinforce our assumption that the deeper $\mathrm{Fe}^{\mathrm{II}}$ maximum may be biologically induced.

Calculated $\mathrm{Fe}^{\mathrm{II}}$ concentrations at night stay at a level that is determined by the light-induced dark reduction $\left(R_{\mathrm{ld}}\right)$. The lowest values are below the analytical detection limit, but concentrations of $\sim 0.1 \mathrm{nM}$ are in good agreement with the field data. The rate of light-induced reduction of ferric iron $\left(R_{\mathrm{Fe}}{ }^{\mathrm{II}}\right)$ is calculated independently for $\mathrm{UVA}, \mathrm{UVB}$, and PAR by the model. From the respective rates for each $\Delta \lambda$, we can conclude that at the surface UV irradiation plays a role that is approximately equal to PAR. This indicates that the much higher normalized initial rate of $\mathrm{Fe}^{\mathrm{III}}$ reduction at lower wavelength is largely compensated by the lower light intensity of the sunlight in this range. At a depth of $1 \mathrm{~m}, R_{\mathrm{Fe}^{\mathrm{II}}}$ (PAR) already largely dominates the rates due to UVA and UVB irradiation.

\section{Significance of Fe redox cycling in freshwater systems}

The results presented here clearly show that, at the surface of two circumneutral lakes $(\mathrm{pH} 8-9), \mathrm{Fe}^{\mathrm{II}}$ is produced in light-induced processes. This is the first study on diurnal $\mathrm{Fe}^{\mathrm{II}}$ cycling in the epilimnion of surface waters where time series of $\mathrm{Fe}^{\mathrm{II}}$ depth profiles are included. These findings, together with literature data, indicate that light-induced reduction of $\mathrm{Fe}^{\mathrm{III}}$ occurs in freshwater as well as in seawater, and that some general pattern, such as $\mathrm{pH}$ dependence and relation to light intensity, can be recognized.

Our data on $\mathrm{Fe}^{\mathrm{II}}$ concentrations may also be compared to those reported in the epilimnion of Lake Kinneret ( $\mathrm{pH} 7-8)$ (Sivan et al. 1998). In Lake Kinneret total and ultrafilterable iron concentrations (71-390 and 7-20 nM, respectively) are comparable to our systems. However, very high $\mathrm{Fe}^{\mathrm{II}}$ concentrations $(50-150 \mathrm{nM})$ were observed in the epilimnion of Lake Kinneret during daytime, whereas $\mathrm{Fe}^{\mathrm{II}}$ concentrations were always below the detection limit $(40 \mathrm{nM})$ during nighttime. More than $66 \%$ of the detected $\mathrm{Fe}^{\mathrm{II}}$ in Lake Kinneret was associated with particles, in contrast to our observations and also to those reported by Waite et al. (1995) in northern Australian surface shelf waters. The findings by Waite et al. and our results suggest that the soluble or finely colloidal iron rather than the particulate iron pool is most influenced by light in sunlit surface waters. The extremely high $\mathrm{Fe}^{\mathrm{II}}$ concentrations reported during daytime in the epilimnion of Lake Kinneret could be due to the analytical method employed, namely colorimetric measurement of $\mathrm{Fe}^{\mathrm{II}}$ concentrations with ferrozine as $\mathrm{Fe}^{\mathrm{II}}$ ligand. Although the different analytical approaches and the limited resolution in time and depth for Lake Kinneret make detailed comparison difficult, the general observation of diel cycling and of biologically induced $\mathrm{Fe}^{\mathrm{II}}$ formation are in good agreement.

Mathematical simulation of the laboratory data on the light-induced reduction of $\mathrm{Fe}^{\mathrm{III}}$ in water samples from Greifensee and Melchsee suggest that in both lakes reaction with $\mathrm{O}_{2}^{-}$could be an important pathway of $\mathrm{Fe}^{\mathrm{IIII}}$ reduction, and possibly the predominant mechanism for $\mathrm{Fe}^{\mathrm{II}}$ production in the epilimnion of these two lakes. The much faster redox cycling of iron in Melchsee, compared with Greifensee, could be due to a higher $\mathrm{O}_{2}^{--}$overall production rate in Melchsee, despite its relatively low DOC content. Studies measuring the rate of $\mathrm{O}_{2}^{--}$production (Micinski et al. 1993) have been limited to seawater. It would be highly rewarding to determine $\mathrm{O}_{2}^{--}$production rates in field and laboratory studies for lake systems with different concentrations and origins of CDOM.

CDOM plays, in any case, a central and yet poorly understood role in the light-induced production of $\mathrm{Fe}^{\mathrm{II}}$ in surface waters, either by providing complexing ligands of $\mathrm{Fe}^{\mathrm{III}}$ and $\mathrm{Fe}^{\mathrm{II}}$ or by acting as a source of superoxide (Micinski et al. 1993). Both photolysis of $\mathrm{Fe}^{\mathrm{III}}-\mathrm{CDOM}$ complexes, and CDOM-sensitized $\mathrm{O}_{2}^{-}$production result in CDOM oxidation and possibly in its breakdown to low-molecular-weight, bioavailable carbon compounds (Kieber et al. 1989). Furthermore, photooxidation will not only reduce the concentration of CDOM, but it can also decrease its specific light absorbance (Morris and Hargreaves 1997). As a consequence of both, decrease in CDOM concentration and CDOM bleaching, the penetration depth of solar radiation, especially in the UVB and UVA regions, into surface waters will increase, affecting mostly high-altitude, oligotrophic lakes.

Our findings in lakes and in laboratory experiments with lakewater samples indicate that a rapid turnover of $\mathrm{Fe}^{\mathrm{II}} / \mathrm{Fe}^{\mathrm{III}}$ takes place in the euphotic zone of circumneutral lakes on a timescale of few minutes. It thus appears that small amounts of reactive $\mathrm{Fe}^{\mathrm{II}}$ and $\mathrm{Fe}^{\mathrm{III}}$ are continuously formed out of a much larger pool of total iron, where most of total iron consists of poorly reactive phases such as $\mathrm{Fe}^{\mathrm{III}}$ oxides and hydroxides. Oxidation of nanomolar concentrations of $\mathrm{Fe}^{\mathrm{II}}$ is expected to result in the formation of small amounts of hydrated and hydrolyzed $\mathrm{Fe}^{\mathrm{III}}$ species, for which membrane bound ligands of eucaryotic freshwater algae may compete successfully with ligands, either biogenic or anthropogenic, present in the surrounding water (Hudson and Morel 1990). Light-induced reduction of $\mathrm{Fe}^{\mathrm{III}}$ is thus expected to play an essential role in providing available iron to the algae in lakes. Additional mechanisms of $\mathrm{Fe}^{\mathrm{II}}$ production are probably related to biological processes and may also contribute to the supply of dissolved, bioavailable iron. The availability of iron to algae in freshwater is, therefore, likely to depend on factors such as light intensity, presence and composition of natural organic matter, and $\mathrm{pH}$, rather than on the total iron concentration.

\section{References}

Albrecht-Gary, A.-M., And A. L. Crumbliss. 1998. Coordination chemistry of siderophores: Thermodynamics and kinetics of iron chelation and release, p. 239-327. In A. Sigel and H. Sigel [eds.]. Iron transport and storage in microorganisms, plants, and animals. Metal ions in biological systems. Dekker.

ANDERSON, M. A., AND F. M. M. Morel. 1982. The influence of aqueous iron chemistry on the uptake of iron by the coastal diatom Thalssiosira weissflogii. Limnol. Oceanogr. 27: 789813.

Barbeau, K., J. W. Moffet, D. A. Caron, P. L. Croot, and D. 
L. ERDNER. 1996. Role of protozoan grazing in relieving iron limitation of phytoplankton. Nature 380: 61-64.

BeHRENFELD, M. J., AND Z. S. Kolber. 1999. Widespread iron limitation of phytoplankton in the South Pacific Ocean. Science 283: $840-843$.

Blough, N. V., AND R. G. ZePP. 1995. Reactive oxygen species in natural waters, p. 280-333. In L. S. Foote, S. S. Valentine, A. Greenbaerg and S. F. Liebman [eds.]. Active oxygen: Reactive oxygen species in chemistry. Chapman and Hall.

BRuland, K. W., J. Donat, AND D. A. Hutchins. 1991. Interactive influences of bioactive trace metals on biological production in oceanic waters. Limnol. Oceanogr. 36: 1555-77.

Cavender Bares, K. K., E. L. Mann, S. W. Chisholm, M. E. ONDRUSEK, AND R. R. BidigaRE. 1999. Differential response of equatorial Pacific phytoplankton to iron fertilization. Limnol. Oceanogr. 44: 237-246.

Chang, C. C. Y., J. S. Kuwabara, and S. P. Pasilis. 1992. Phosphate and iron limitation of phytoplankton biomass in Lake Tahoe. Can. J. Fish. Aquat. Sci. 49: 1206-15.

CoAle, K. H., K. S. Johnson, S. E. Fitzwater, And M. E. GorDON. 1996. A massive phytoplankton bloom induced by an ecosystem-scale iron fertilization experiment in the equatorial Pacific Ocean. Nature 383: 495-508.

Collienne, R. H. 1983. Photoreduction of iron in the epilimnion of acidic lakes. Limnol. Oceanogr. 28: 83-100.

Deng, Y., AND W. STUMm. 1994. Reactivity of aquatic iron(III) oxyhydroxides-implications for redox cycling of iron in natural waters. Appl. Geochem. 9: 23-36.

Elrod, V. A., K. S. Johnson, And K. H. CoAle. 1991. Determination of subnanomolar levels of iron(II) and total dissolved iron in seawater by flow injection analysis with chemiluminescence detection. Anal. Chem. 63: 893-98.

EMMENEGGER, L. 1999. Light-induced redox cycling of iron in lakes. Ph.D. thesis. Swiss Federal Institute of Technology Zurich (ETHZ).

- D. W. King, L. SigG, AND B. Sulzberger. 1998. Oxidation kinetics of $\mathrm{Fe}^{\mathrm{II}}$ in a eutrophic Swiss lake. Environ. Sci. Technol. 32: 2990-2996.

Evans, J. C., AND E. E. Prepas. 1997. Relative importance of iron and molybdenum in restricting phytoplankton biomass in high phosphorus saline lakes. Limnol. Oceanogr. 42: 461-72.

FAust, B. C., AND R. G. ZePP. 1993. Photochemistry of aqueous iron(III)-polycarboxylate complexes: Roles in the chemistry of atmospheric and surface waters. Environ. Sci. Technol. 27: 2517-2522.

Gledhill, M., AND C. M. G. van DEN Berg. 1995. Measurement of the redox speciation of iron in seawater by catalytic cathodic stripping voltametry. Mar. Chem. 50: 51-61.

Goldstone, J. V, AND B. M. VoelKer. 2000. Chemistry of superoxide radical in seawater: CDOM associated sink of superoxide in coastal waters. Environ. Sci. Technol. 34: 1043-1048.

Goudsmit, G.-H., AND A. WÜEST. 1999. Interior and basin-wide diapycnal mixing in stratified water: A comparison of dissipation and diffusivity, p. 145-163. In P. A. Davis [ed.]. Mixing and dispersion in stable stratified flows. Clarendon Press.

HaAg, W. R., J. Hoigné, E. Gassmann, and A. M. Braun. 1984. Singlet oxygen in surface waters-part II: quantum yields of its production by some natural humic materials as function of wavelength. Chemosphere 13: 641-50.

Hamilton-TaYlor, J., AND W. Davison. 1995. Redox-driven cycling of trace elements in lakes, p. 1-333. In A. Lerman, D. Imboden, and J. Gat [eds.]. Physics and chemistry of lakes. Springer.

HARrison, G. I., AND F. M. M. Morel. 1986. Response of the marine diatom Thalassiosira weissflogii to iron stress. Limnol. Oceanogr. 31: 989-97.
Hatchard, C. G., AND C. A. Parker. 1956. A new sensitive chemical actinometer II. Potassium ferrioxalate as a standard chemical actinometer. Proc. Royal Society Lond. 235: 518-536.

Hong, H., AND D. R. Kester. 1986. Redox state of iron in the offshore waters of Peru. Limnol. Oceanogr. 31: 512-24.

Hudson, R. J. M., AND F. M. M. Morel. 1990. Iron transport in marine phytoplankton: Kinetics of cellular and medium coordination reactions. Limnol. Oceanogr. 35: 1002-20.

Johnson, K. S., K. H. Coale, V. A. Elrod, and N. W. Tindale. 1994. Iron photochemistry in seawater from the equatorial $\mathrm{Pa}$ cific. Mar. Chem. 46: 319-34.

Jones, G. J., B. P. PAlenik, And F. M. M. Morel. 1987. Trace metal reduction by phytoplankton: The role of plasmalemma redox enzymes. J. Phycol. 23: 237-44.

KIEBER, D. J., J. McDAnIEL, AND K. MopPer. 1989. Photochemical source of biological substrates in sea water: implications for carbon cycling. Nature 341: 637-39.

KING, D. W. 1998. Role of carbonate speciation on the oxidation rate of $\mathrm{Fe}^{\mathrm{II}}$ in aquatic systems. Environ. Sci. Technol. 32: 2997-3003.

, R. A. Aldrich, AND S. E. Charnecki. 1993. Photochemical redox cycling of iron in $\mathrm{NaCl}$ solutions. Mar. Chem. 44: 105-20.

, AND R. FARLOW. 2000. Role of carbonate speciation on the oxidation of $\mathrm{Fe}$ (II) by $\mathrm{H}_{2} \mathrm{O}_{2}$. Mar. Chem. 70: 201-209.

- , H. A. Lounsburry, AND F. J. Millero. 1995. Rates and mechanism of $\mathrm{Fe}^{\mathrm{II}}$ oxidation at nanomolar total iron concentrations. Environ. Sci. Technol. 29: 818-24.

KNIGHT, R. J., AND R. N. SyLVA. 1975. Spectrophotometric investigation of iron(III) hydrolysis in light and heavy water at $25^{\circ} \mathrm{C}$. Inorg. Nucl. Chem. 37: 779-83.

LARSON, R. A. 1978. Environmental chemistry of reactive oxygen species, p. 197-246. Critical reviews in environmental control, 8. CRC.

Micinski, E., L. A. Ball, And O. C. Zafiriou. 1993. Photochemical oxygen activation: superoxide radical detection and production rates in the eastern caribbean. J. Geophys. Res. 98: 2299-2306.

Miller, W. L., AND D. R. Kester. 1988. Hydrogen peroxide measurement in seawater by (p-hydroxyphenyl)acetic acid dimerization. Anal. Chem. 60: 2711-2715.

—, D. W. King, J. Lin, AND D. R. Kester. 1995. Photochemical redox cycling of iron in coastal seawater. Mar. Chem. 50: 63-77.

Millero, F. J. 1997. The influence of iron on carbon dioxide in surface seawater, p. 381-398. In A. Gianguzza, E. Pelizzetti and S. Sammartano [eds.]. Marine Chemistry. Academic.

Morris, D. P., AND B. R. Hargreaves. 1997. The role of photochemical degradation of dissolved organic carbon in regulating the UV transparency of three lakes on the Pocono Plateau. Limnol. Oceanogr. 42: 239-249.

O'Sullivan, D. W., And A. K. Hanson. 1991. Measurement of $\mathrm{Fe}^{\mathrm{II}}$ in surface water of the equatorial Pacific. Limnol. Oceanogr. 36: $1727-41$.

Petasne, R. G., AND R. G. ZIKA. 1987. Fate of superoxide in coastal sea water. Nature 325: 516-518.

Price, N. M., AND F. M. M. Morel. 1990. Role of extracellular enzymatic reactions in natural waters, p. 235-258. In W. Stumm [ed.]. Aquatic chemical kinetics. John Wiley \& Sons.

Reichert, P. 1994. Aquasim-a tool for simulation and data analysis of aquatic systems. Water Sci. Technol. 30: 21-30.

Rush, J. D., AND B. H. J. BIELSKI. 1985. Pulse radiolytic studies of the reaction of $\mathrm{HO}_{2} \mathrm{O}_{2}^{-}$with $\mathrm{Fe}(\mathrm{II}) / \mathrm{Fe}$ (III) ions. The reactivity of $\mathrm{HO}_{2} / \mathrm{O}_{2}{ }^{-}$with ferric ions and its implication on the occurrence of the Haber-Weiss reaction. J. Phys. Chem. 89: 5062-6. 
SCHELSKE, C. L. 1962. Iron, organic matter, and other factors limiting primary productivity in a marl lake. Science 136: 45-46.

- F. F. HoOper, AND E. J. HAERTL. 1962. Responses of a marl lake to chelated iron and fertilizer. Ecology 43: 646-53.

SedlaK, D. L., AND J. HoignÉ. 1993. The role of copper and oxalate in the redox cycling of iron in atmospheric waters. Atmos. Environ. Part A Gen. Top. 14: 2173-2185.

SifFert, C. 1989. L'effet de la lumière sur la dissolution des oxydes de fer(III) dans les milieux aqueux. Ph.D. thesis. ETHZ.

Sivan, O., Y. Erel, D. Mandler, AND A. Nishri. 1998. The dynamic redox chemistry of iron in the epilimnion of Lake Kinneret (Sea of Galilee). Geochim. Cosmochim. Acta 62: 565576.

STURZENEGGER, V. 1989. Wasserstoffperoxid in Oberflächengewässern: Photochemische Produktion und Abbau. Ph.D. thesis. Swiss Federal Institute for Technology Zurich (ETHZ).

Sulzberger, B., J. L. Schnoor, R. Giovanoli, J. G. Hering, AND J. Zobrist. 1990. Biogeochemistry of iron in an acidic lake. Aquat. Sci. 52: 57-74.

SundA, W. G. In press. Bioavailability and bioaccumulation of iron in seawater. In K. A. Hunter and D. Turner [eds.]. The biochemistry of iron in seawater. IUPAC series on analytical and physical chemistry of environmental systems, v. 7. John Wiley \& Sons.

, And S. A. Huntsman. 1995. Iron uptake and growth limitation in oceanic and coastal phytoplankton. Mar. Chem. 50: 189-206.

- D. G. Swift, And S. A. Huntsman. 1991. Low iron requirement for growth in oceanic phytoplankton. Nature 351: $55-57$.

TEVINI, M., AND D.-P. HÄDER. 1985. Allgemeine photobiologie. Thieme.

Tratnyek, P. G., AND J. Hoigné. 1994. Photo-oxidation of 2.4.6trimethylphenol in aqueous laboratory solutions and natural waters: kinetics of reaction with singlet oxygen. J. Photochem. Photobiol. 84: 153-60. von Piechowski, M., T. Nauser, J. Hoigné, and R. E. BüHLeR. 1993. $\mathrm{O}_{2}^{-}$decay catalyzed by $\mathrm{Cu}^{2+}$ and $\mathrm{Cu}^{+}$ions in aqueous solutions: a pulse radiolysis study for atmospheric chemistry. Ber. Bunsen-Ges. Phys. Chem. 97: 762-771.

Voelker, B. M., F. M. M. Morel, AND B. Sulzberger. 1997. Iron redox cycling in surface waters: Effects of humic substances and light. Environ. Sci. Technol. 31: 1004-1011.

, AND D. L. SEDLAK. 1995. Iron reduction by photoproduced superoxide in seawater. Mar. Chem. 50: 93-102.

, - AND O. C. ZAFIRIOU. 2000. Chemistry of superoxide radical in seawater: Reactions with organic $\mathrm{Cu}$ complexes. Environ. Sci. Technol. 34: 1036-1042.

, AND B. SulzBerger. 1996. Effects of fulvic acid on Fe oxidation by hydrogen peroxide. Environ. Sci. Technol. 30: 1106-1114.

Waite, T. D., AND F. M. M. Morel. 1984. Photoreductive dissolution of colloidal iron oxides in natural waters. Environ. Sci. Technol. 18: 860-68.

, R. Szymaczak, Q. I. Espey, and M. J. Furnas. 1995. Diel variations in iron speciation in northern Australia. Mar. Chem. 50: 79-91.

Wetzel, R. G. 1965. Nutritional aspects of algal productivity in marl lakes with particular reference to entrichment bioassays and their interpretation. Mem. Ist. Ital. Idrobiol. 18: 137-57.

Xue, H., D. Kistler, And L. Sigg. 1995. Competition of copper and zinc for strong ligands in a eutrophic lake. Limnol. Oceanogr. 40: $1142-52$.

ZAFIRIOU, O. C. 1990. Chemistry of superoxide ion-radical $\left(\mathrm{O}_{2}^{-}\right)$in seawater. I. $p K^{*}{ }_{\text {asw }}(\mathrm{HOO})$ and uncatalyzed dismutation kinetics studied by pulse radiolysis. Mar. Chem. 30: 31-43.

, B. M. Voelker, and D. L. SedlaK. 1998. Chemistry of the superoxide radical $\left(\mathrm{O}_{2}^{-}\right)$in seawater: Reactions with inorganic copper complexes. J. Phys. Chem. 102: 5693-5700.

Received: 20 October 1999

Amended: 5 September 2000 Accepted: 18 September 2000 